J Med Chem. 2017 November 22; 60(22): 9360-9375. doi:10.1021/acs.jmedchem.7b01356.

\title{
Improvement of Cell Permeability of Human Neuronal Nitric Oxide Synthase Inhibitors Using Potent and Selective 2- Aminopyridine-Based Scaffolds with a Fluorobenzene Linker
}

\author{
Ha T. Do ${ }^{\dagger,}$, Heng-Yen Wang ${ }^{\dagger, ¥}$, Huiying $\mathrm{Li}^{\S}$, Georges Chreifi ${ }^{\S}$, Thomas L. Poulos ${ }^{\S},{ }^{\star}$, and \\ Richard B. Silverman ${ }^{\dagger}{ }^{*}$ \\ tDepartment of Chemistry, Department of Molecular Biosciences, Chemistry of Life Processes \\ Institute, Center for Molecular Innovation and Drug Discovery, Center for Developmental \\ Therapeutics, Northwestern University, 2145 Sheridan Road, Evanston, Illinois 60208-3113, \\ United States \\ §Departments of Molecular Biology and Biochemistry, Pharmaceutical Sciences, and Chemistry, \\ University of California, Irvine, California 92697-3900, United States
}

\begin{abstract}
Inhibition of neuronal nitric oxide synthase (nNOS) is a promising therapeutic approach to treat neurodegenerative diseases. Recently, we have achieved considerable progress in improving the potency and isoform selectivity of human nNOS inhibitors bearing a 2-aminopyridine scaffold. However, these inhibitors still suffered from too low cell membrane permeability to enter into CNS drug development. We report herein our studies to improve permeability of nNOS inhibitors as measured by both PAMPA-BBB and Caco-2 assays. The most permeable compound (12) in this study still preserves excellent potency with human nNOS $\left(K_{\mathrm{i}}=26 \mathrm{nM}\right)$ and very high selectivity over other NOS isoforms, especially human eNOS (hnNOS/heNOS $=2799$, the highest hnNOS/ heNOS ratio we have obtained to date). X-ray crystallographic analysis reveals that $\mathbf{1 2}$ adopts a similar binding mode in both rat and human nNOS, in which the 2-aminopyridine and the fluorobenzene linker form crucial hydrogen bonds with glutamate and tyrosine residues, respectively.
\end{abstract}

\section{Graphical Abstract}

\footnotetext{
*Corresponding Authors: (R.B.S.) Tel:+1 847491 5653. Fax: +1 847491 7713. Agman@chem.northwestern.edu. (T.L.P.) Tel:+1 949 824 7020. poulos@uci.edu.

$¥$ These authors contributed equally.

Notes

The authors declare no competing financial interest.

Supporting Information

Crystallographic data collection and refinement statistics for rat nNOS, human nNOS, and human eNOS; crystal structures of rnNOS and hnNOS-7, rnNOS and hnNOS-13, rnNOS-11 and rnNOS-19c; UV-Vis absorption spectrum of hemoglobin without and in the presence of compound 12; synthesis and analytical data for compounds 20, 22a-d, 23a, 27, and 31a; molecular formula strings. Accession Codes: PDB codes for X-ray structures described in this study are as follow: rnNOS-7, 6AUQ; rnNOS-8, 6AUR; rnNOS-10, 6AUS; rnNOS-12, 6AUT; rnNOS-13, 6AUU; rnNOS-16, 6AUV; rnNOS-17, 6AUW; rnNOS-18, 6AUX; hnNOS-7, 6AUY; hnNOS-8, 6AUZ; hnNOS-10, 6AU0; hnNOS-12, 6AU1; hnNOS-13, 6AU2; hnNOS-16, 6AU3; hnNOS-17, 6AU4; hnNOS-18, 6AU5; heNOS-8, 6AU6; heNOS-12, 6AU7. Authors will release the atomic coordinates and experimental data upon article publication.
} 


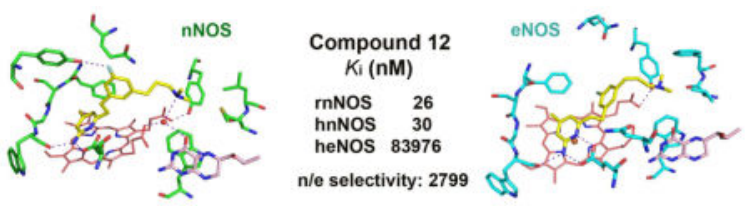

\section{Keywords}

human neuronal nitric oxide synthase inhibitor; 2-aminopyridine; fluorobenzene linker; neurodegenerative diseases; Parkinson's disease; PAMPA-BBB; Caco-2; cell-permeability; CNS drug development

\section{INTRODUCTION}

Nitric oxide (NO) is a unique cell signaling molecule involving in many physiological functions including neurotransmission, vasodilation, smooth muscle relaxation, vascular regulation, and immune response. ${ }^{1-3} \mathrm{NO}$ is generated in cells by a family of enzymes called nitric oxide synthase (NOS), which catalyzes the oxidation of L-arginine (L-Arg) to Lcitrulline. Three different isoforms of NOS have been found in mammals, of which two isoforms, neuronal NOS (nNOS) and endothelial NOS (eNOS), are constitutively expressed in relation to the calcium levels in cells, while the third one, inducible NOS (iNOS), is expressed in response to cell inflammation. ${ }^{4}$ These isoforms are distributed in various tissues and responsible for different physiological functions: nNOS is mainly localized in the nervous system and is involved in neuronal communication; eNOS is found in the endothelium and participates in regulation of vascular pressure and vasodilation; and iNOS is located in macrophages and is essential for the innate immune system. ${ }^{5}$

Although NO possesses many essential functions in cells, its overproduction has been implicated in various pathological disorders. ${ }^{6-9}$ In the central nervous system (CNS), excess NO produced by nNOS has been linked to diverse neuronal disorders, such as Parkinson's disease, Alzheimer's disease, Huntington's disease, amyotrophic lateral sclerosis, ischemic stroke, and migraines. ${ }^{6,10,11}$ At high concentrations, NO causes excessive nitration and/or nitrosylation of proteins, leading to their degradation and misfolding. ${ }^{12}$ Moreover, overproduced NO can also react with superoxide anion to form a highly reactive oxidant, peroxynitrite, which causes DNA damage, lipid peroxidation, and mitochondria dysfunction, and therefore triggers neuronal apoptosis or necrosis. ${ }^{13}$ These processes lead to synaptic damage and neurotransmission impairment, which are commonly observed in symptoms of neurodegenerative diseases. ${ }^{14}$ Consequently, limiting NO overproduction through the inhibition of nNOS is a potential therapeutic approach for the treatment of neuronal disorders.

NOS isoforms exist as homodimers, in which each monomer consists of one N-terminal oxygenase domain and one $\mathrm{C}$-terminal reductase domain connected to each other by a calmodulin binding region. The former domain contains a non-catalytic zinc, tetrahydrobiopterin $\left(\mathrm{H}_{4} \mathrm{~B}\right)$, and a heme-containing catalytic active site that binds the substrate, $\mathrm{L}$ Arg. The latter domain, the $\mathrm{C}$-terminal reductase, employs nicotinamide adenine 
dinucleotide phosphate (NADPH), flavin adenine dinucleotide (FAD), and flavin mononucleotide (FMN) to shuttle electrons to the iron center of the heme cofactor in the catalytic active site, where L-Arg gets oxidized to L-citrulline and releases NO. ${ }^{4}$ Because of the high similarity in the structure of the active sites of the three NOS isoforms and the diverse involvement of NO signaling in many cellular physiological functions, selective inhibition of nNOS over eNOS and iNOS to develop a new therapeutic with minimal side effects for neurodegenerative diseases is a critical challenge. ${ }^{15}$ Moreover, the presence of the blood-brain barrier (BBB) formed by endothelial cells with tight junctions creates an additional challenge for CNS drug development, as it greatly limits the delivery of drugs into the brain. ${ }^{16}$

Nevertheless, a large number of compounds with good potency and high selectivity for inhibiting nNOS over eNOS and iNOS have been reported. Most of them are designed to compete with L-Arg binding at the active site of the enzyme. ${ }^{17}$ These inhibitors, however, still suffer from low membrane permeability and poor ability to cross the BBB as a result of their high basicity and/or polarity. In the past few years our group has pursued various medicinal chemistry approaches to improve the pharmacokinetic values of nNOS inhibitors, such as incorporating intramolecular hydrogen bonds (1) ${ }^{18}$ converting to prodrugs (2), ${ }^{19}$ modulating the amine basicity (3), ${ }^{20}$ and replacing an essential pharmacophore, such as replacement of the 2-aminopyridine with a 2-imidazolylpyrimidine $(4)^{21}$ or 2 aminoquinoline (5) 22 (Figure 1). Although some pharmacokinetic improvement has been achieved, these approaches can result in a diminution in activity, especially for human nNOS, the ultimate target for neurodegenerative diseases, and in the selectivity over human eNOS.

Recently, we reported a series of nNOS inhibitors containing a 2-aminopyridine anchor attached to a pyridine ring linker and an amine tail (6, Figure 1) ${ }^{23}$ Compared to other nNOS inhibitors, $\mathbf{6}$ is considerably easier to synthesize and possesses excellent potency toward rat and human nNOS $\left(K_{\mathrm{i}}(\mathrm{rnNOS})=16 \mathrm{nM} ; K_{\mathrm{i}}(\mathrm{hnNOS})=13 \mathrm{nM}\right)$ as well as high selectivity over iNOS and heNOS $(\mathrm{n} / \mathrm{i}=116$ and $\mathrm{hn} / \mathrm{he}=1831)$. Additionally, pharmacokinetic studies revealed that this compound displayed very poor CYPs inhibition, little human microsome metabolism, and only $20 \%$ human plasma protein binding. Nevertheless, $\mathbf{6}$ expresses little Caco-2 permeability, an indication of poor predicted permeation through the BBB, thereby rendering low therapeutic value.

Our further investigations, reported herein, have been focused on improving the permeability of 6 while retaining its excellent potency and selectivity. In previous reports, ${ }^{23,} 24$ we demonstrated that the 2-aminopyridine moiety was crucial for the key interactions of nNOS inhibitors with Glu-592 and Glu-597 in the active site of rnNOS and hnNOS, respectively. Hence, structural modifications have been focused on the middle ring linker and the amine tail. First, the middle pyridine linker was replaced by other aromatic rings. Various linker moieties (7-10) were chosen to explore the activity as well as enhance the lipophilicity. Second, methylation of the secondary amine (11-14) was carried out in a strategy to improve the permeability by reduction in the number of $\mathrm{H}$-bond donors. Third, reduction of the number of rotatable bonds within the molecule was investigated by incorporating biaryl linkers bearing an amino tail at both meta- (16) and para- (17) positions as well as 
modulation of the basicity of the amino tail group in molecules containing these rigid linkers (15). Finally, introduction of lipophilic moieties to the biaryl linkers (18-19) was employed to maximize the lipophilicity of the modified compounds. All compounds were then investigated for their nNOS inhibition and selectivity over eNOS and iNOS. Analogues with high potency and selectivity were further examined in a parallel artificial membrane permeability for blood brain barrier (PAMPA-BBB) assay for their permeability and in a Caco-2 assay for their P-glycoprotein (P-gp) substrate liability.

\section{RESULT AND DISCUSSION}

\section{Chemistry}

To replace the pyridine linker in $\mathbf{6}$ by other aromatic rings, different benzylic bromide compounds (21a-d), which are commercially available, were substituted with lithiated pyrrolyl-4,6-dimethylpyridine (20) to generate intermediates 22a-d (Scheme 1).

The generated intermediates (22a-c) were then coupled with either $N$-Boc- $N$-methylpropargylamine (23a) or 3-dimethylamino-1-propyne (23b) via Sonagashira cross-coupling to afford alkynes carrying Boc-protected secondary amine (24a-c) or tertiary amine (26a-c), respectively. A sequence of Boc deprotection, alkyne reduction, and pyrrole deprotection of 24a-c provided desired compounds 7-9. In a similar pathway of alkyne reduction and pyrrole deprotection, compounds 11-13 were obtained from 26a-c (Scheme 2).

It was desirable to synthesize compounds 10 and 14, containing a cyanophenyl linker, since our previous studies showed that incorporation of a cyano group into potential molecules helps improve their nNOS activity and selectivity, especially with human nNOS. ${ }^{22,} 24$ Intermediate 27, containing a cyanophenyl linker, was synthesized from bromophenyl precursor $22 \mathrm{~d}$ by treatment with $\mathrm{CuCN}$ in $\mathrm{DMF}$ at $150{ }^{\circ} \mathrm{C}$. Sonogashira coupling was then performed on 27 to install the amine tails. Unlike the synthetic route for 7-9 and 11-13, pyrrole deprotection in the synthesis of target compounds $\mathbf{1 0}$ and $\mathbf{1 4}$ was performed before alkyne reduction to avoid overreduction of the pyrrole ring by $\mathrm{Pd} / \mathrm{C}, \mathrm{H}_{2}$ (Scheme 3 ).

The syntheses of compounds containing pyridine-based biaryl linkers were started with construction of the biaryl moiety using Suzuki coupling of $\mathbf{3 0}$ with different boronic acids (31a-c) as shown in Scheme 4. Two assessments were investigated in this modification with pyridine-based biaryl linkers. First, the boronic acid of Boc-protected aniline 31a was used to modulate the basicity of the tail amino group. Reduction of the $\mathrm{p} K_{\mathrm{a}}$ not only improves the permeability of the resulting compound but also reduces its P-gp substrate liability. ${ }^{25}$ Second, compounds in which the amino group is connected to the pyridine-based biaryl linkers via one extended methylene group at both meta- or para- positions were synthesized to evaluate the effect of these connectivities on the biological activity and selectivity of the resulting inhibitors. Boc-deprotection of 32a obtained from the aforementioned Suzuki reactions yielded intermediate 33a, while reductive amination of $\mathbf{3 2} \mathbf{b}-\mathbf{c}$ with the $N$ methylamine hydrochloride salt generated 33b-c. Pyrrole deprotection of the three intermediates (33a-c) afforded the final desired products (15-17, Scheme 4). 
To maximize the possible increase in cell membrane permeability, a new set of compounds that contains both lipophilicity and rigidity enhancement were synthesized. These compounds were designed to consist of a biaryl linker containing a fluorophenyl ring. Following a similar synthetic route used for analogues 15-17, compounds 18 and 19 were successfully constructed using $\mathbf{2 2 b}$ in place of intermediate $\mathbf{3 0}$ (Scheme 4).

\section{Biological activity}

The hemoglobin NO capture assay ${ }^{26}$ was used to determine the inhibitory constants $\left(K_{\mathrm{i}}\right)$ of synthesized compounds 7-19. First, these compounds were tested against rat nNOS and murine iNOS to evaluate their inhibitory activity and isoform selectivity. On the basis of the screening results, the compounds with high potency and selectivity were further assayed against human nNOS and human eNOS. The $K_{\mathrm{i}}$ and the selectivity values of $\mathbf{7 - 1 9}$, as well as those of compound $\mathbf{6}$ for comparison, are summarized in Table 1 . The selectivity for nNOS over iNOS (n/i) was obtained by comparing $K_{\mathrm{i}}$ values of rat nNOS and murine iNOS on account of the ease of expression and purification of these enzymes. For selectivity against nNOS over eNOS, $K_{\mathrm{i}}$ values obtained from human nNOS and human eNOS were used (hn/he) to achieve structure-activity relationships (SAR) closer to the human system. Additionally, a cross comparison of compound activities against nNOS of different species (human vs. rat, $\mathrm{hn} / \mathrm{rn}$ ) was also evaluated because this is valuable information in evaluating translation from preclinical to clinical studies.

In the first series of compounds, modified by replacing the middle pyridine linker with other aromatic rings (7-10), modification caused effects on both potency and selectivity. Particularly, when phenyl or fluorophenyl linkers were employed in place of pyridine, the potencies with rat nNOS and human nNOS of the resulting compounds ( $\mathbf{7}$ and $\mathbf{8}$, respectively) are slightly decreased compared to those of $\mathbf{6}$. When the aromatic linkers contain a bulkier and more electron withdrawing group, i.e., trifluoromethyl- (9) or cyano(10) groups, the resulting compounds display a dramatic drop in the inhibitory activity over nNOS in both species. This result suggests a different effect from the modification of the middle aromatic ring compared to what we observed previously for the other pharmacophores, such as a 2-aminoquinoline anchoring head with an amine tail or a 2aminopyridine with a diamine tail; $; 2,24$ in both cases incorporation of a nitrile on the middle phenyl ring generally resulted in improvement in both potency and selectivity. This trend, however, does not consistently occur in the current scaffold of nNOS inhibitors, which consists of a 2-aminopyridine anchoring head and a middle aromatic ring with a long amine tail.

X-ray crystal structures of these inhibitors bound to NOS were determined to reveal the structural basis for these new observations. It has been shown that ${ }^{23}$ the middle pyridine ring of $\mathbf{6}$ can establish an upward binding mode with the nitrogen atom forming a H-bond to a Tyr residue (Tyr-562 in rnNOS and Tyr-567 in hnNOS). Once the middle pyridine is replaced by a phenyl ring in $\mathbf{7}$ this $\mathrm{H}$-bonding capability is removed. As shown in the structure of rnNOS-7 (Figure S1A), while the anchoring 2-aminopyridine can still make bifurcated H-bonds with Glu-592, the middle phenyl ring bends back on to the heme, and the long amine tail does not make any favorable contacts with the protein. A similar situation 
is also observed in the hnNOS-7 structure (Figure S1B). As the result of these changes in the interactions with nNOS, the nNOS inhibitory potency of $\mathbf{7}$ drops by 3 - to 4 -fold compared to those of 6 (Table 1).

The upward binding mode of the middle aromatic ring is reestablished when the phenyl ring is replaced by a fluorophenyl ring. The crystal structures of $\mathbf{8}$ bound to both rnNOS and hnNOS (Figures 3A and 3B, respectively) clearly show the H-bond from the fluorine atom to Tyr-562 (rnNOS, $2.7 \AA$ ) or Tyr-567 (hnNOS, $2.5 \AA$ ). In addition, the tail amine moiety can also H-bond $(2.6-2.8 \AA)$ with the water molecule bridging between the heme propionate $\mathrm{A}$ and $\mathrm{H}_{4} \mathrm{~B}$. The "3-points" $\mathrm{H}$-bonding interactions (i.e., head, middle, and tail) shown with compound $\mathbf{8}$ are similar to what were seen for $\mathbf{6}$, although the binding affinity of 8 to both nNOS enzymes is 3 - to 5 -fold weaker than that of $\mathbf{6}$, possibly the result of the nonpolar nature of the fluorophenyl ring in $\mathbf{8}$ versus the polar pyridine ring in $\mathbf{6}$.

Compound 8 also retains good isoform selectivity compared to lead compound $\mathbf{6}(\mathbf{6}, \mathrm{n} / \mathrm{i}=$ $118, \mathrm{hn} / \mathrm{he}=1761 ; \mathbf{8}, \mathrm{n} / \mathrm{i}=113, \mathrm{hn} / \mathrm{he}=610$ ). The structure of heNOS-8 (Figure 3C) indicates that while the 2-aminopyridine group can still H-bond with Glu-361, the middle fluorophenyl ring and the tail amine show a high degree of uncertainty with incomplete electron densities. The ethylene linker between the 2-aminopyridine and the middle phenyl ring is not pointing upward as seen in the structures of $\mathbf{8}$ bound to nNOS (Figure $3 \mathrm{~A}$ and 3B). As a result, the fluorophenyl ring no longer H-bonds with Tyr331. Moreover, the disordered tail amine does not make any H-bond with protein or water. All together, the lack of these interactions could be responsible for the low inhibition of this compound against heNOS, which results in its high $\mathrm{hn} / \mathrm{he}$ ratio.

The ratio of activity between $\mathrm{hnNOS}$ and $\mathrm{rnNOS}$ of $\mathbf{7 - 1 0}(\mathrm{hn} / \mathrm{rn})$ was also determined to evaluate the potential translation of these inhibitors from preclinical data to a clinical study. This ratio was aimed to be as close to 1.0 as possible so that there will be little to no significant difference in the amount of inhibitors used in rat and human dosage. The primary sequence of human nNOS and rat nNOS is more than $93 \%$ identical, and the nNOS active site is quite conserved between these two species. ${ }^{24}$ The difference between them that is relevant to inhibitor binding in a peripheral pocket is that the nonpolar Leu337 residue in rnNOS is replaced by a bulkier and polar His342 residue in hnNOS. Compounds 7-10, which contain a non-bulky alkylamino tail were designed not to reach into this pocket, therefore resulting in a close-to-1.0 hn/rn ratio. As shown in Table 1, although 7-10 displayed slightly lower inhibition to human nNOS than rat nNOS, their $\mathrm{hn} / \mathrm{rn}$ ratio is still less than 2.0, especially, $\mathbf{7}$ and $\mathbf{8}$, the two favorably potent and selective compounds.

Our second approach to improve the permeability of $\mathbf{6}$, in which the secondary amino tail of 7-10 was replaced by a tertiary amino tail to reduce the number of hydrogen bond donors in the lead molecule, gave the next series of compounds (11-14). In the previous study, ${ }^{23}$ the H-bonds of the secondary amino tail group of $\mathbf{6}$ with a bridging water molecule interacting with both the heme and $\mathrm{H}_{4} \mathrm{~B}$ moieties of nNOS, was proposed to account for the improvement in potency of $\mathbf{6}$ with hnNOS. Hence, the conversion of the secondary amine in the tail of 7-10 to a tertiary amine in the corresponding analogues (11-14) may potentially diminish the hnNOS inhibitory activity of these resulting compounds. However, we found 
that the secondary-to-tertiary amine conversion had little effect on the inhibition activity of 11-14 compared to those of 7-10. In fact, 12 is more potent with both rat and human nNOS than its secondary amine analogue $(\mathbf{8})$ with $K_{\mathrm{i}}$ values close to those of lead compound $\mathbf{6}$.

Moreover, 12 displays a remarkable improvement in isoform selectivity surpassing those of 6, especially over heNOS (hn/he = 2799). Additionally, 12 also has a favorable $\mathrm{hn} / \mathrm{rn}$ ratio (1.2). X-ray crystal structures of $\mathbf{1 2}$ bound to rnNOS, hnNOS and heNOS are shown in Figure 4.

Similar to lead compound 6 and its secondary amine analogue 7, compound 12 retains the upward binding mode in both rnNOS (Figure 4A) and hnNOS (Figure 4B) with its fluorophenyl ring forming a H-bond with a Tyr residue (Tyr562 in rnNOS or Tyr567 in hnNOS). The tertiary amine can still approach the bridging water molecule between heme propionate $\mathrm{A}$ and $\mathrm{H}_{4} \mathrm{~B}$. The only difference from $\mathbf{7}$ is that the tertiary amino group of $\mathbf{1 2}$ is now a $\mathrm{H}$-bond acceptor instead of the donor of 7. This bridging water is not visible in the hnNOS-12 structure because of the moderate data resolution $(2.45 \AA)$, but is supposed to be there, interacting with the tertiary amino group of $\mathbf{1 2}$.

Compared to 8 and 6, 12 exhibited a much greater improvement in the selectivity for hnNOS over heNOS (4.5 times more than $\mathbf{8}$ and 1.6 times more than 6). The X-ray structure of 12 bound to heNOS (Figure 4C) reveals that the fluorophenyl linker adopts a bent-over binding mode with the ring pressing against the heme moiety, which is different from the structure of the heNOS-8 complex, in which the middle ring is flipped over $180^{\circ}$ with the fluorine atom pointing toward Asn366. The tertiary amino group is not making H-bond or other favorable contacts with the protein, resulting in a 2 -fold weaker potency than $\mathbf{8}$. Therefore, compound 12 becomes the most selective inhibitor in the series with $\mathrm{hn} / \mathrm{he}=2799$.

As the $K_{\mathrm{i}}$ values listed in Table 1 indicate that a trifluoromethylphenyl (9 and 13) or a benzonitrile (10 and 14) as the middle ring leads to poor inhibitors, we attempted to look for the underlying reasons in crystal structures. We did not obtain decent data for rnNOS-9 but data for both rnNOS-13 (Figure S2A) and hnNOS-13 (Figure S2B) allowed us to model the inhibitor in the active site. The 2-aminopyridine group H-bonds with Glu-592 (rnNOS) or Glu-597 (hnNOS), and the ethylene linker connected to the middle aromatic ring also bends upward as that observed in the rnNOS-12 structure. However, because of the bulky trifluoromethyl group, the phenyl ring itself cannot go upward; instead, the trifluoromethyl group fits into a pocket between Glu-592 and Arg-596 in rnNOS, making non-bonded interactions with the two side chains. The long amine tail is highly flexible with weak density, approaching heme propionate D but without forming a H-bond. Losing H-bonds from the middle ring and the tail amine in $\mathbf{1 3}$ (or 9) are likely the reasons behind their poor binding.

Using a benzonitrile ring as the middle aromatic linker had some success in the 2aminoquinoline- ${ }^{22}$ and the 2 -aminopyridine- 24 containing inhibitors in the past, but it showed the opposite effects with compounds $\mathbf{1 0}$ or $\mathbf{1 4}$ here. We were able to obtain the structures of rnNOS-10 (Figure 5A) and hnNOS-10 (Figure 5B). In these structures, the benzonitrile ring position in $\mathbf{1 0}$ is similar to that found for the fluorophenyl ring in $\mathbf{8}$ with the cyano group protruding next to Asp-597 (rnNOS) or Asp-602 (hnNOS) at a distance of 2.9 - 
3.0 ̊. This interaction cannot be a H-bond unless the Asp residue is protonated. The tail amino group is flexible but managed to make a H-bond with the bridging water near the $\mathrm{H}_{4} \mathrm{~B}$. Given the poor inhibitory potency, the close contacts involving the cyano group may even be considered as unfavorable clashes.

Why would a middle benzonitrile ring make 2-aminoquinoline compounds better inhibitors $^{22}$ but not the 2-aminopyridine analogues described here? The bulkier 2aminoquinoline group actually pushes the middle benzonitrile ring to a position that allows the cyano group to fit into a narrow cleft between Met-570 and Tyr-706 in rnNOS (Figure $\mathrm{S} 3 \mathrm{~A})$. In addition, the cyano group H-bonds with a structural water molecule in the cleft, which is in turn H-bonds with the protein backbone. In this way, the benzonitrile moiety of those 2-aminoquinoline compounds is tightly sequestered in the protein cleft, giving high potency. In the case of the 2 -aminopyridine compound with a diamino tail ${ }^{24}$ the middle benzonitrile ring points in an opposite direction, close to Ser-477 in rnNOS (Figure S3B). That direction is restrained by the diamine, which tightly interacts with the heme propionate A. As a result of 3-point H-bonds - from head, middle, and tail - a very potent inhibitor is obtained. Therefore, whether or not a functional group can make favorable contacts (often H-bonds) determines if this group contributes positively to the potency of the inhibitor.

The next modification in our study was to increase the rigidity, and therefore potentially enhance cell membrane permeability, of the modified analogues. Compounds 15-17, containing a pyridine-based biaryl linker, were then synthesized. To maintain a similar distance of the amino tail group to the pyridine ring (via four bonds as found in 6), 15 was prepared with a methylaniline in the tail. As such, the basicity of the tail amino group was also modulated ( $p \mathrm{~K}_{\mathrm{a}}$ of $\mathbf{1 5}=4.29$ predicted by ChemAxon software, https:// www.chemaxon.com/). The assay with rnNOS showed that the reduction in the basicity of the tail amino group drastically reduced the nNOS inhibition of $\mathbf{1 5}$, which is 100 times less potent than 6. No crystal structures were determined with nNOS for compound $\mathbf{1 5}$ because of its poor binding affinity.

To increase the basicity of the amino tail, we prepared 16, which has almost the same constitution as $\mathbf{1 5}$, but with a methylene group extending between the amino group and the aromatic biaryl linker. The nNOS inhibitory activity of analogue $\mathbf{1 6}$ (predicted $p \mathrm{~K}_{\mathrm{a}}=9.49$ for the tail amine) was restored and was comparable to 7 and $\mathbf{8}$ (Table 1). Crystal structures of rnNOS-16 (Figure 5A) and hnNOS-16 (Figure 5B) reveal a similar upward binding mode of 6 , in which the middle pyridine ring H-bonds with Tyr562 (rnNOS) or Tyr567 (hnNOS). One distinction exists in the tail amino group: in rnNOS the amino group makes a H-bond with a water molecule bridging between heme propionate $\mathrm{A}$ and $\mathrm{H}_{4} \mathrm{~B}$, whereas in hnNOS the amino group displaces the water molecule and directly H-bonds with both the heme propionate and $\mathrm{H}_{4} \mathrm{~B}$.

To determine the impact of different connectivity to the inhibitor-enzyme interactions, the position of the (methylamino)methylene group relative to the pyridine ring was also changed from meta- for $\mathbf{1 6}$ to para- for 17. As shown in Figure 6,17 binds to hnNOS in an upward mode with its middle pyridine H-bonded to Tyr567; however, in rnNOS the middle pyridine bends back to interact with heme propionate $\mathrm{D}$. In both cases, the tail amino group in $\mathbf{1 7}$ can 
no longer interact with either heme propionate or $\mathrm{H}_{4} \mathrm{~B}$ because of its para-position from the pyridine ring. The potency of $\mathbf{1 7}$ is slightly poorer than that of $\mathbf{1 6}$ as a result of the lack of this tail interaction.

Knowing the structure of $\mathbf{1 6}$ and $\mathbf{1 7}$, we can comment on why $\mathbf{1 5}$ is a much poorer inhibitor. The tail amino group in $\mathbf{1 5}$ is in an aniline, thus having lower basicity. More importantly, the rigidity and short arm of this amino group keep it from reaching out to the $\mathrm{H}_{4} \mathrm{~B}$ site water molecule.

To obtain analogues with increased cell membrane, and therefore BBB permeability, we also assessed a combined modification in which both molecular rigidity (as found for 15-17) and lipophilicity (as found for 7-10) were employed to give 18-19. The chemical structures of 18 and 19 are almost identical to $\mathbf{1 6}$ and $\mathbf{1 7}$, respectively, except for the fact that the pyridine-based biaryl linker is replaced by a fluorophenyl-based biaryl linker. Biological assays revealed that $\mathbf{1 8}$ retains excellent inhibitory activity against nNOS $\left(\mathbf{1 8}, K_{\mathrm{i}}(\operatorname{rnNOS})=\right.$ $\left.44 \mathrm{nM}, K_{\mathrm{i}}(\mathrm{hnNOS})=83 \mathrm{nM}\right)$ while there is a marked drop in activity for $19\left(K_{\mathrm{i}}(\mathrm{rnNOS})=\right.$ $\left.185 \mathrm{nM}, K_{\mathrm{i}}(\mathrm{hnNOS})=362 \mathrm{nM}\right)$. This trend seems to be consistent with biaryl-linker analogues in which compounds with the (methylamino)methylene group at the metaposition $(\mathbf{1 6}, \mathbf{1 8})$ gave greater potency than those with a para-substituted (methylamino)methylene $(\mathbf{1 7}, \mathbf{1 9})$. Additionally, there is no significant change in nNOS inhibition between two meta-analogues, while the fluorophenyl-containing analogue (18) displays more than 2-fold higher selectivity for hnNOS over heNOS $(\mathbf{1 6}, \mathrm{hn} / \mathrm{he}=106 ; \mathbf{1 8}$, $\mathrm{hn} / \mathrm{he}=234$ ).

Two different binding modes were observed for $\mathbf{1 8}$ bound to rnNOS and hnNOS. The middle fluorophenyl ring of $\mathbf{1 8}$ bends back against the heme in rnNOS, as shown in Figure 7A, while its tail amino group still reaches to the water molecule bridging between heme propionate $\mathrm{A}$ and the $\mathrm{H}_{4} \mathrm{~B}$. In contrast, the fluorophenyl ring of $\mathbf{1 8}$ in the hnNOS structure (Figure 7B) turns upward making a H-bond with Tyr567, while the tail amino group folds back to make a H-bond with the $\mathrm{H}_{4} \mathrm{~B}$ site water molecule. Either binding mode can achieve fairly good potency with nNOS. An attempt at getting a heNOS-18 structure was made. The binding mode was found similar to that shown in rnNOS; that is, the middle fluorophenyl ring bends back against the heme. However, in heNOS the tail phenyl ring and amino group are more disordered without making any favorable contacts with the protein or the water molecule, which also prevented the refinement completion. In reference to the structures of rnNOS-17 and hnNOS-17 (Figure 6), it is easy to understand why 19 is a poor inhibitor. The para-position of the middle fluorophenyl ring makes the tail amino group impossible to reach the $\mathrm{H}_{4} \mathrm{~B}$ site water molecule no matter which binding mode 19 might adopt in nNOS.

\section{Permeability}

Compounds $7,12,16$, and 18 , with high potency and selectivity for nNOS, were selected for a permeability study. The in-vitro permeability of selected compounds was measured using the parallel artificial membrane permeability for blood brain barrier (PAMPA-BBB) assay. ${ }^{28}$ Additionally, the efflux ratio (ER) was determined with a Caco-2 assay to evaluate their Pgp liability. The PAMPA-BBB assay was firstly developed by Di et. al. ${ }^{28}$ and has been 
reported to be one of the most efficient and low-cost assays to evaluate the BBB permeation of CNS candidates at the early stage of development. ${ }^{16,29,30}$ In this assay, porcine brain lipid is used as an artificial membrane to predict the passive permeability of tested compounds. Since the BBB has a tight junction between endothelial cells, transcellular passive diffusion is the major pathway for CNS drugs to enter the brain. ${ }^{25}$ Five commercial drugs (Table 2) were used as standard compounds to establish and validate our in-house assay. Two drugs, verapamil and theophylline, were also used as positive and negative controls, respectively, during each permeability test of the selected nNOS inhibitors (see Experimental Section for details). Compared to reported values in the literature (Table 2), ${ }^{28}$ the effective permeability $\left(\mathrm{P}_{\mathrm{e}}\right)$ values of commercial drugs obtained under our conditions are slightly higher. Therefore, a higher cutoff to classify a compound as CNS (+) or CNS (-) was used. If $\mathrm{P}_{\mathrm{e}}$ of a compound is larger than $4.0 \times 10^{-6} \mathrm{~cm} / \mathrm{s}$ (compared to a $2.0 \times 10^{-6} \mathrm{~cm} / \mathrm{s}$ cutoff value in Di's report), ${ }^{28}$ the compound was predicted to have good potential ability to cross the BBB. Table 2 summarizes $\mathrm{P}_{\mathrm{e}}$ values of five commercial-drug standards and our selected nNOS inhibitors $(\mathbf{7}, \mathbf{1 2}, \mathbf{1 6}$, and 18). The results reveal that all the selected nNOS inhibitors exhibit a predicted CNS (+) with $\mathrm{P}_{\mathrm{e}}$ values up to $17.4 \times 10^{-6} \mathrm{~cm} / \mathrm{s}$. Compound 16 $\left(\mathrm{P}_{\mathrm{e}}=5.56 \times 10^{-6} \mathrm{~cm} / \mathrm{s}\right)$, with a pyridine-based biaryl linker, displays the lowest permeability among the selected compounds, indicating that the presence of the pyridine ring significantly hinders the permeability of nNOS inhibitors, which is consistent with the littleto-no permeability found for lead compound $\mathbf{6}$ in the Caco-2 assay.

Replacement of the pyridine linker by a fluorobenzene ring in nNOS inhibitors was found to greatly help increase the $\mathrm{P}_{\mathrm{e}}$ value. For example, 18, containing a fluorophenyl-based biaryl linker, exhibits a 3 -fold higher $\mathrm{P}_{\mathrm{e}}\left(17.41 \times 10^{-6} \mathrm{~cm} / \mathrm{s}\right)$ than that of $\mathbf{1 6}$ with a pyridine-based biaryl linker $\left(16, \mathrm{P}_{\mathrm{e}}=5.56 \times 10^{-6} \mathrm{~cm} / \mathrm{s}\right)$. Compound 12, with a fluorophenyl linker and a tertiary amino tail, exhibits a $\mathrm{P}_{\mathrm{e}}$ of ca. 1.5 -fold higher than that of $\mathbf{7}$, which contains a phenyl ring linker and a secondary amino tail.

The PAMPA-BBB assay also supports combining molecular rigidity and lipophilicity to obtain greater permeability. While retaining excellent potency and selectivity, compound $\mathbf{1 8}$ exhibits a comparable $\mathrm{P}_{\mathrm{e}}$ to that of the commercial CNS drugs verapamil and desipramine.

Finally, the efflux ratio (ER) of the four selected analogs was determined using a Caco-2 assay to evaluate their P-gp substrate liability. Efflux transporters contribute significantly to limiting the brain penetration of drugs; P-glycoprotein (P-gp) and breast cancer resistant protein (BCRP) are the two most important ATP-driven efflux transporters at the BBB, of which P-gp has a larger substrate specificity and therefore higher impact than BCRP. ${ }^{16}$ The bidirectional Caco-2 assay is commonly used to identify the P-gp liability of a drug, ${ }^{31}$ in which the permeability of a compound is measured by its ability to cross a monolayer of colon cells with expressed $\mathrm{P}$-gp from two directions, either from apical to basal $(\mathrm{A} \rightarrow \mathrm{B})$ or from basal to apical $(\mathrm{B} \rightarrow \mathrm{A})$ wells. The efflux ratio $(\mathrm{ER})$ is the ratio of the apparent permeability $\left(\mathrm{P}_{\text {app }}\right.$ ) of $\mathrm{B} \rightarrow \mathrm{A}$ over $\mathrm{A} \rightarrow \mathrm{B}$. The higher the ER a compound has, the less potential to penetrate the BBB. $\mathrm{P}_{\text {app }}$ and ER of the selected nNOS inhibitors $(\mathbf{7 , 1 2 , 1 6}$, and 18) and control compounds are shown in Table 3. The results indicate that the four selected analogues all exhibit better permeability than $\mathbf{6}$. Compound 16, which has a low $\mathrm{P}_{\mathrm{e}}$ value in the PAMPA-BBB assay $\left(\mathrm{P}_{\mathrm{e}}=5.56 \times 10^{-6} \mathrm{~cm} / \mathrm{s}\right)$, also displays the lowest permeability 
among the series in the Caco-2 assay with the highest efflux ratio, indicating that this biaryl containing pyridine compound is not only a poor penetrant but also a very strong P-gp substrate. The Caco- 2 results again confirm that replacement of the pyridine ring by a fluorobenzene ring significantly increases permeability. Specifically, $\mathbf{1 8}$ displays an ER less than one-sixth that of $\mathbf{1 6}$, although it still displays a high ER with only $28 \%$ recovery in the $\mathrm{A} \rightarrow \mathrm{B}$ direction. This result also suggests that compound $\mathbf{1 8}$ is retained in the lipid layer of colon cells, which is possibly the result of its high lipophilicity. Obtaining the optimal lipophilicity is key in CNS drug development to deliver drugs into the brain; compounds with insufficient lipophilicity will suffer from poor penetration, while compounds with excessive lipophilicity will have increased risks of toxicity and instability, as well as retention in the cell membrane, preventing it from crossing the BBB. ${ }^{25,32}$ Of the four selected compounds, 12 exhibits the lowest ER (5.9) with high recovery percentage in both directions. This compound also expresses a favorable permeability in the PAMPA-BBB assay (Table 2). Although its ER value is still out of the therapeutic range for CNS drugs (usually ER $<3$ ), ${ }^{33}$ there has been significant improvement in the permeability as demonstrated by both PAMPA-BBB and Caco-2 assays compared to lead compound 6 . The insights from these modifications help to understand further the structure-activity relationship and cell permeability of nNOS inhibitors.

\section{CONCLUSION}

We have designed and synthesized a new series of potent and selective human nNOS inhibitors based on the 2-aminopyridine scaffold aimed at improving their cell membrane permeability, and therefore increasing their ability to cross the BBB. Different strategies, involving replacing the polar and basic middle pyridine linker, reducing the number of hydrogen bond donors, and increasing the rigidity of the molecular skeletons, have been used. We discovered that the combination of exchanging the middle pyridine linker with a more lipophilic fluorobenzene linker and the use of a tertiary amine in place of a secondary amine resulted in compound 12, which not only retains excellent inhibition for human nNOS $\left(K_{\mathrm{i}}=26 \mathrm{nM}\right)$ and a tremendous selectivity over human eNOS $(\mathrm{hn} / \mathrm{he}=2799$, which is the highest selectivity ratio we have obtained to date) but also increases the permeability of the compound compared to lead compound $\mathbf{6}$. X-ray diffraction analysis of $\mathbf{1 2}$ bound to rat and human nNOS reveals that the fluorine atom of the fluorobenzene linker forms a H-bonds with Tyr-567 in hnNOS and Tyr-562 in rnNOS, which mimics what was previously observed for the nitrogen of the pyridine linker in compound $\mathbf{6}$. However, introducing many aromatic rings in $\mathbf{1 8}$ resulted in excessive lipophilicity, which caused retention in the cell membrane. These results serve as the basis for further exploration of the properties of these potent and selective nNOS inhibitors.

\section{EXPERIMENTAL SECTION}

\section{Chemistry}

General Procedures-All reagents were purchased from Sigma-Aldrich and used without further purification. Compound 20, 23a, and $\mathbf{3 0}$ were prepared according to our previous report. ${ }^{23}$ Arylbromides $\mathbf{2 1 a - d}$ are commercially available. Alkyne $\mathbf{2 3 b}$ and boronic 
acids 31a-c were also obtained from commercial sources. Anhydrous solvents (THF, $\mathrm{CH}_{2} \mathrm{Cl}_{2}$, DMF) were purified before use by passing through a column composed of activated alumina and a supported copper redox catalyst. Thin layer chromatography (TLC) was performed on silica gel 60 F254 pre-coated plates $(0.25 \mathrm{~mm})$ from Silicycle, and components were visualized by ultraviolet light $(254 \mathrm{~nm})$ and/or $\mathrm{KMnO}_{4}$ or ninhydrin stain. Flash column chromatography was performed on an Agilent 971-FP automated flash purification system with a Varian column station and various Silicycle cartridges (4-80 g, 40-63 $\mu \mathrm{m}, 60 \AA$ A). ${ }^{1} \mathrm{H}$ and ${ }^{13} \mathrm{C}$ NMR spectra were recorded on a Bruker Avance-III NMR spectrometer at $500 \mathrm{MHz}$ and $126 \mathrm{MHz}$, respectively, in $\mathrm{CDCl}_{3}$ or $\mathrm{CD}_{3} \mathrm{OD}$. Chemical shifts were reported in ppm, multiplicities are indicated by $\mathrm{s}=\operatorname{singlet}, \mathrm{d}=$ doublet, $\mathrm{t}=$ triplet, $\mathrm{q}=$ quartet, sep = septet, $\mathrm{dd}=$ doublet of doublet, $\mathrm{dt}=$ doublet of triplet, $\mathrm{m}=$ multiplet, $\mathrm{br}=$ broad resonance. Coupling constants ' $\mathrm{J}$ ' were reported in Hz. High resolution mass spectral data were obtained on an Agilent 6210 LC-TOF spectrometer in the positive ion mode using electrospray ionization with an Agilent G1312A HPLC pump and an Agilent G1367B autoinjector at the Integrated Molecular Structure Education and Research Center (IMSERC), Northwestern University. The purity of compounds was tested by using a reserved-phase analytical Agilent Infinity 1260 HPLC with an Agilent Poroshell 120 ECC18 column, detecting with UV absorbance at $254 \mathrm{~nm}$. All compounds undergoing biological tested had $>95 \%$ purity. The preparations of Sonagashira coupling products, Suzuki coupling products, and final compounds are described below, while the synthesis of intermediates 22c-d is presented in the Supporting Information.

General Procedure A: Sonagashira Cross Coupling: A microwave vial was charged with $\mathrm{Pd}\left(\mathrm{PPh}_{3}\right)_{4}(5 \mathrm{~mol} \%), \mathrm{CuI}$ (5 mol \%), and aryl bromide 22a, 22b, 22c, or 27 (1 equiv.). The mixtures were diluted with triethylamine to form a $0.16 \mathrm{M}$ solution followed by the addition of alkyne 23a or 23b (1.5-2 equiv.). The microwave vial was capped, and the reaction mixture was stirred at $90{ }^{\circ} \mathrm{C}$ for $20 \mathrm{~h}$. The cap was removed, and the reaction mixture was diluted with ethyl acetate and filtered. The filtrate was washed with water, ammonium chloride, and brine, dried with $\mathrm{Na}_{2} \mathrm{SO}_{4}$, and concentrated under reduced pressure. The crude product mixture was purified by flash column chromatography to give $\mathbf{2 4 a - 2 4 c , ~ 2 6 a - 2 6 c}$, 28a, and 28c.

General Procedure B: Boc Deprotection, Alkyne Reduction, and Pyrrole Deprotection: Compounds 24a-24c (1 equiv.) were diluted with DCM to form a $0.1 \mathrm{M}$ solution followed by addition of TFA ( $20 \%$ volume). The reaction mixture was allowed to stir at r.t. for $1 \mathrm{~h}$. At this time, the crude product was concentrated under reduced pressure, diluted with $\mathrm{CH}_{2} \mathrm{Cl}_{2}$, and washed with sat. $\mathrm{NaHCO}_{3}$. The organic layer was dried over $\mathrm{Na}_{2} \mathrm{SO}_{4}$ and concentrated to give crude products $25 \mathbf{a}-\mathbf{2 5} \mathbf{c}$. The crude product was used for further steps without purification. A scintillation vial was charged with $10 \% \mathrm{wt} . \mathrm{Pd} / \mathrm{C}$ and crude product 25a-25c ( 1 equiv.). The mixtures were diluted with methanol to form a $0.1 \mathrm{M}$ solution. The reaction mixture was stirred at r.t. for $20 \mathrm{~h}$ under a hydrogen balloon (1 atm). At this time, the crude product was filtered, and the filtrate was concentrated under reduced pressure to give a crude product. A microwave vial was charged with reduction crude product (1 equiv.) and $\mathrm{NH}_{2} \mathrm{OH} \cdot \mathrm{HCl}$ (3-4 equiv.). The mixtures were diluted with EtOH/ water $(2: 1)$ to form a $0.16 \mathrm{M}$ solution. The microwave vial was then capped and the reaction 
mixture was stirred at $100{ }^{\circ} \mathrm{C}$ for $20 \mathrm{~h}$. The cap was removed, and the reaction mixture was concentrated under reduced pressure. The crude product mixture was purified by flash chromatography to give $\mathbf{7 , 8}$, and $\mathbf{9}$.

General Procedure C: Alkyne Reduction and Pyrrole Deprotection: A scintillation vial was charged with $10 \%$ wt. $\mathrm{Pd} / \mathrm{C}$ and 26a-26c (1 equiv.). The mixtures were diluted with methanol to form a $0.1 \mathrm{M}$ solution. The reaction mixture was stirred at r.t. for $20 \mathrm{~h}$ under a hydrogen balloon ( $1 \mathrm{~atm}$ ), then the crude product was filtered, and the filtrate was concentrated under reduced pressure. The crude product was subjected to 2,5dimethylpyrrole deprotection without purification. A microwave vial was charged with crude reduction products 26a-26c ( 1 equiv.) and $\mathrm{NH}_{2} \mathrm{OH} \cdot \mathrm{HCl}$ (3-4 equiv.). The mixtures were diluted with EtOH/water (2:1) to form a $0.16 \mathrm{M}$ solution. The microwave vial was capped, and the reaction mixture was stirred at $100{ }^{\circ} \mathrm{C}$ for $20 \mathrm{~h}$. The cap was removed, and the reaction mixture was concentrated under reduced pressure. The crude product mixture was purified by flash chromatography to give 11, 12, and 13 .

General procedure D: Preparation of 32a-c and 34a-b (Suzuki cross-coupling): A microwave vial was charged with $\mathrm{Pd}\left(\mathrm{PPh}_{3}\right)_{4}(5 \mathrm{~mol} \%), \mathrm{K}_{2} \mathrm{CO}_{3}$ (2 equiv.), boronic acid 31a-c (1.5 equiv.), and 30 (1 equiv.). The mixture was diluted with THF/water (4:1) to form a $0.2 \mathrm{M}$ solution. The microwave vial was capped, and the reaction mixture was stirred at $80^{\circ} \mathrm{C}$ for $20 \mathrm{~h}$. The cap was removed, and the reaction mixture was diluted with ethyl acetate. The crude product was filtered, the filtrate was dried over $\mathrm{Na}_{2} \mathrm{SO}_{4}$, and concentrated under reduced pressure to give reaction crude $32 \mathbf{a}-\mathbf{c}$ and $\mathbf{3 4 a}-\mathbf{b}$.

\section{General Procedure E: Preparation of 33b-c and 35a-b (Reductive amination): A} scintillation vial was charged with $\mathrm{N}$-methylamine hydrochloride salt (3 equiv.) and $\mathrm{NaOAc}$ (3 equiv.), and the mixtures were diluted with $\mathrm{MeOH}$ to form a $0.1 \mathrm{M}$ solution. The resulting slurry was allowed to stir at $25^{\circ} \mathrm{C}$ for $15 \mathrm{~min}$. The slurry was then transferred to a scintillation vial charged with 1 equiv. of the crude product from the Suzuki cross-coupling (32b-c or 34a-b). The reaction mixtures were then allowed to stir at $25^{\circ} \mathrm{C}$ for $1 \mathrm{~h}$. At this time, $\mathrm{Na}_{2} \mathrm{SO}_{4}$ was added to the scintillation vial, and the mixture was filtered. The filtrate was cooled to $0{ }^{\circ} \mathrm{C}$ followed by addition of $\mathrm{NaBH}_{4}$ ( 3 equiv.). The reaction mixture was allowed to warm to r.t and stir for $1 \mathrm{~h}$. The reaction was quenched with water, and the methanol was removed under reduced pressure. The aqueous mixture was extracted with DCM three times, and the organic layers were collected, dried over $\mathrm{Na}_{2} \mathrm{SO}_{4}$, and concentrated to give the crude product, which was purified by flash chromatography to give 33b-c and 35a-b.

General Procedure F: Preparation of 15-19 (Pyrrole Deprotection): A microwave vial was charged with 33a-c or 35a-b (1 equiv.) and $\mathrm{NH}_{2} \mathrm{OH} \cdot \mathrm{HCl}$ (3-4 equiv.). The mixtures were diluted with $\mathrm{EtOH} /$ water $(2: 1)$ to form a $0.16 \mathrm{M}$ solution. The microwave vial was capped, and the reaction mixture was stirred at $100{ }^{\circ} \mathrm{C}$ for $20 \mathrm{~h}$. The cap was removed, and the reaction mixture was concentrated under reduced pressure. The crude product mixture was purified by flash chromatography to give 15-19. 
4-Methyl-6-(3-(3-(methylamino)propyl)phenethyl)pyridin-2-amine (7): Compound 7 was synthesized according to general procedure B using $24 \mathbf{a}(130.0 \mathrm{mg}, 0.284 \mathrm{mmol})$, TFA (0.5 $\mathrm{ml}), 10 \%$ wt. $\mathrm{Pd} / \mathrm{C}(10.8 \mathrm{mg})$, and $\mathrm{NH}_{2} \mathrm{OH} \cdot \mathrm{HCl}(59.1 \mathrm{mg}) .7$ was isolated as a brown oil (55.5 mg, 69\%) after flash column chromatography (MeOH: DCM 3:7). ${ }^{1} \mathrm{H}$ NMR (500 MHz, Methanol- $\left.d_{4}\right): \delta 7.20-7.18(\mathrm{~m}, 2 \mathrm{H}), 7.10-7.08(\mathrm{~m}, 2 \mathrm{H}), 6.71(\mathrm{~s}, 1 \mathrm{H}), 6.59(\mathrm{~s}, 1 \mathrm{H})$, 3.03-3.00 (m, 6H), 2.71-2.69 (m, 5H), 2.32 (s, 3H), 2.08-1.97 (m, 2H); ${ }^{13} \mathrm{C}$ NMR (125 MHz, Methanol- $\left.d_{4}\right): \delta 157.6,154.3,148.6,140.7,140.0,128.5,128.4,126.4,126.3,113.8,109.5$, 48.8, 48.7, 34.5, 34.4, 32.1, 27.6, 20.9; HRMS ESI: calcd. For $\mathrm{C}_{18} \mathrm{H}_{26} \mathrm{~N}_{3}[\mathrm{M}+\mathrm{H}]^{+}$, 284.2121; found, 284.2121 .

\section{6-(3-Fluoro-5-(3-(methylamino)propyl)phenethyl)-4-methylpyridin-2-amine (8):}

Compound $\mathbf{8}$ was synthesized according to general procedure B using $\mathbf{2 4 b}(135.0 \mathrm{mg}, 0.284$ $\mathrm{mmol}), \mathrm{TFA}(0.58 \mathrm{ml}), 10 \%$ wt. $\mathrm{Pd} / \mathrm{C}(17.0 \mathrm{mg})$, and $\mathrm{NH}_{2} \mathrm{OH} \cdot \mathrm{HCl}(64.0 \mathrm{mg}) .8$ was isolated as a brown oil (74.5 mg, 87.07\%) after flash column chromatography (MeOH: DCM= 3:7). ${ }^{1} \mathrm{H}$ NMR $\left(500 \mathrm{MHz}\right.$, Methanol- $\left.d_{4}\right): \delta 7.02(\mathrm{~s}, 1 \mathrm{H}), 6.89-6.85(\mathrm{~m}, 2 \mathrm{H}), 6.73(\mathrm{~s}, 1 \mathrm{H})$, $6.62(\mathrm{~s}, 1 \mathrm{H}), 3.04-3.01(\mathrm{~m}, 6 \mathrm{H}), 2.73-2.70(\mathrm{~m}, 5 \mathrm{H}), 2.33(\mathrm{~s}, 3 \mathrm{H}), 2.06-2.00(\mathrm{~m}, 2 \mathrm{H}) ;{ }^{13} \mathrm{C}$ NMR $\left(125 \mathrm{MHz}\right.$, Methanol- $\left.d_{4}\right): \delta 163.0\left(\mathrm{~d}, J_{\mathrm{C}-\mathrm{F}}=243.0 \mathrm{~Hz}\right), 157.6,154.4,148.3,143.4(\mathrm{~d}$, $\left.J_{\mathrm{C}-\mathrm{F}}=7.8 \mathrm{~Hz}\right), 142.6\left(\mathrm{~d}, J_{\mathrm{C}-\mathrm{F}}=7.8 \mathrm{~Hz}\right), 124.2\left(\mathrm{~d}, J_{\mathrm{C}-\mathrm{F}}=2.1 \mathrm{~Hz}\right), 113.7,112.9\left(\mathrm{~d}, J_{\mathrm{C}-\mathrm{F}}=\right.$ $21.3 \mathrm{~Hz}), 112.8\left(\mathrm{~d}, J_{\mathrm{C}-\mathrm{F}}=21.4 \mathrm{~Hz}\right), 109.5,48.5,34.1,34.0,32.4,31.8,27.3,20.6$; HRMS ESI: calcd. For $\mathrm{C}_{18} \mathrm{H}_{25} \mathrm{FN}_{3}[\mathrm{M}+\mathrm{H}]^{+}, 302.2027$; found, 302.2031 .

4-Methyl-6-(3-(3-(methylamino)propyl)-5-(trifluoromethyl)phenethyl)pyridin-2-amine (9): Compound 9 was synthesized according to general procedure B using $24 \mathbf{c}(222 \mathrm{mg}, 0.42$ $\mathrm{mmol})$, TFA $(0.8 \mathrm{ml}), 10 \%$ wt. $\mathrm{Pd} / \mathrm{C}(16.1 \mathrm{mg})$, and $\mathrm{NH}_{2} \mathrm{OH} \cdot \mathrm{HCl}(72 \mathrm{mg}) .9$ was isolated as a brown oil $(80.2 \mathrm{mg}, 54 \%)$ after flash column chromatography (MeOH: DCM 1:3). ${ }^{1} \mathrm{H}$ NMR $\left(500 \mathrm{MHz}\right.$, Methanol- $\left.d_{4}\right): \delta 7.54(\mathrm{~s}, 1 \mathrm{H}), 7.43(\mathrm{~s}, 1 \mathrm{H}), 7.40(\mathrm{~s}, 1 \mathrm{H}), 6.74(\mathrm{~s}, 1 \mathrm{H}), 6.62$ (s, 1H), 3.16-3.12 (m, 2H), 3.09-3.06 (m, 4H), $2.83(\mathrm{t}, J=8.0 \mathrm{~Hz}, 2 \mathrm{H}), 2.74(\mathrm{~s}, 3 \mathrm{H}), 2.34$ (s, $3 \mathrm{H}), 2.11-2.05(\mathrm{~m}, 2 \mathrm{H}) ;{ }^{13} \mathrm{C}$ NMR (125 MHz, Methanol- $\left.d_{4}\right): \delta 157.5,154.5,148.2,142.3$, $141.3,132.3,130.6\left(\mathrm{q}, J_{\mathrm{C}-\mathrm{F}}=32.5 \mathrm{~Hz}\right), 124.3\left(\mathrm{q}, J_{\mathrm{C}-\mathrm{F}}=270 \mathrm{~Hz}\right), 122.9\left(\mathrm{~d}, J_{\mathrm{C}-\mathrm{F}}=3 \mathrm{~Hz}\right)$, $122.8\left(\mathrm{~d}, J_{\mathrm{C}-\mathrm{F}}=3 \mathrm{~Hz}\right), 113.8,109.6,48.5,34.1,34.0,32.4,31.8,27.3$, 20.6. HRMS ESI: calcd. For $\mathrm{C}_{19} \mathrm{H}_{24} \mathrm{~F}_{3} \mathrm{~N}_{3}[\mathrm{M}+\mathrm{H}]^{+}, 352.1995$; found, 352.2011.

3-(2-(6-Amino-4-methylpyridin-2-yl)ethyl)-5-(3-(methylamino)propyl)benzonitrile (10): Compound 10 was synthesized by Boc deprotection of 28a followed by pyrroledeprotection, and alkyne-reduction. 10 (182.7 $\mathrm{mg}, 0.38 \mathrm{mmol})$ was diluted with DCM to form a $0.1 \mathrm{M}$ solution followed by addition of TFA ( $20 \%$ volume). The reaction mixture was allowed to stir at r.t. for $1 \mathrm{~h}$. At this time, the crude product was concentrated under reduced pressure, diluted with $\mathrm{DCM}$, and washed with sat. $\mathrm{NaHCO}_{3}$. The organic layer was dried over $\mathrm{MgSO}_{4}$ and concentrated to give $\mathbf{2 8 b}$. The crude product was used for further steps without purification. $\mathbf{2 8 b}$ was subjected to pyrrole deprotection according to general procedure $\mathrm{B}$ using $\mathrm{NH}_{2} \mathrm{OH} \cdot \mathrm{HCl}(82 \mathrm{mg})$ and $\mathrm{EtOH} /$ water $(2 / 1,2.1 \mathrm{~mL})$. 29a was isolated as a light yellow oil (49.3 mg, 43\%) after flash column chromatography (MeOH: DCM 1:3). A scintillation vial was charged with $10 \%$ wt. Pd/C (4.6 mg) and 29a (49.3 mg). The mixtures were diluted with methanol to form a $0.1 \mathrm{M}$ solution. The reaction mixture was stirred at r.t. for $20 \mathrm{~h}$ under hydrogen gas, then filtered, and the filtrate was concentrated under reduced 
pressure to give 10. ${ }^{1} \mathrm{H}$ NMR $\left(500 \mathrm{MHz}\right.$, Methanol- $\left.d_{4}\right): \delta 7.64(\mathrm{~s}, 2 \mathrm{H}), 7.52(\mathrm{~s}, 1 \mathrm{H}), 7.39(\mathrm{~s}$, $1 \mathrm{H}), 6.71(\mathrm{~s}, 1 \mathrm{H}), 6.61(\mathrm{~s}, 1 \mathrm{H}), 3.08-3.01(\mathrm{~m}, 8 \mathrm{H}), 2.79-2.73(\mathrm{~m}, 2 \mathrm{H}), 2.71(\mathrm{~s}, 3 \mathrm{H}), 2.32(\mathrm{~s}$, $3 \mathrm{H}), 2.07-2.04(\mathrm{~m}, 2 \mathrm{H}) ;{ }^{13} \mathrm{C}$ NMR $\left(125 \mathrm{MHz}\right.$, Methanol- $\left.d_{4}\right): \delta 157.5,157.4,154.5,148.5$, 141.3, 140.6, 134.0, 132.0, 125.6, 125.5, 113.7, 109.5, 48.5, 34.3, 34.1, 32.4, 31.8, 27.3, 20.6. HRMS ESI: calcd. For $\mathrm{C}_{19} \mathrm{H}_{24} \mathrm{~N}_{4}[\mathrm{M}+\mathrm{H}]^{+}, 309.2073$; found, 309.2081 .

6-(3-(3-(Dimethylamino)propyl)phenethyl)-4-methylpyridin-2-amine (11): Compound 11 was synthesized according to general procedure $\mathrm{C}$ using $\mathbf{2 6 a}$ ( $89.4 \mathrm{mg}, 0.2408 \mathrm{mmol}), 10 \%$ wt. $\mathrm{Pd} / \mathrm{C}(12.3 \mathrm{mg})$, and $\mathrm{NH}_{2} \mathrm{OH} \cdot \mathrm{HCl}(53.2 \mathrm{mg}) .11$ was isolated as a brown oil (57.9 mg, $81 \%$ ) after flash column chromatography (MeOH: DCM 3:7). ${ }^{1} \mathrm{H}$ NMR $(500 \mathrm{MHz}$, methanol- $\left.d_{4}\right): \delta 7.22(\mathrm{t}, J=7.5 \mathrm{~Hz}, 1 \mathrm{H}), 7.19(\mathrm{~s}, 1 \mathrm{H}), 7.12-7.08(\mathrm{~m}, 2 \mathrm{H}), 6.68(\mathrm{~s}, 1 \mathrm{H}), 6.59$ (s, 1H), 3.17-3.14 (m, 2H), 3.03-3.01 (m, 4H), $2.89(\mathrm{~s}, 6 \mathrm{H}), 2.71-2.68(\mathrm{~m}, 2 \mathrm{H}), 2.33(\mathrm{~s}, 3 \mathrm{H})$, 2.09-2.03 (m, 2H); ${ }^{13} \mathrm{C}$ NMR (125 MHz, methanol- $\left.d_{4}\right): \delta 157.6,154.4,148.7,140.5,140.0$, 128.5, 128.3, 126.4, 126.2, 113.7, 109.4, 57.2, 42.1, 34.4, 34.3, 31.9, 26.0, 20.6; HRMS ESI: calcd. For $\mathrm{C}_{19} \mathrm{H}_{28} \mathrm{~N}_{3}[\mathrm{M}+\mathrm{H}]^{+}, 298.2278$; found, 298.2279 .

6-(3-(3-(Dimethylamino)propyl)-5-fluorophenethyl)-4-methylpyridin-2-amine (12): Compound 12 was synthesized according to general procedure $\mathrm{C}$ using $\mathbf{2 6 \mathbf { b }}(189.5 \mathrm{mg}$, $0.4869 \mathrm{mmol}), 10 \%$ wt. $\mathrm{Pd} / \mathrm{C}(20.1 \mathrm{mg})$, and $\mathrm{NH}_{2} \mathrm{OH} \cdot \mathrm{HCl}(94.1 \mathrm{mg})$. Compound 12 was isolated as a brown oil $(118.6 \mathrm{mg}, 77 \%)$ after flash column chromatography (MeOH: DCM 3:7). ${ }^{1} \mathrm{H}$ NMR $\left(500 \mathrm{MHz}\right.$, methanol- $\left.d_{4}\right): \delta 7.04(\mathrm{~s}, 1 \mathrm{H}), 6.93(\mathrm{~d}, J=9.5 \mathrm{~Hz}, 2 \mathrm{H}), 6.71(\mathrm{~s}$, $1 \mathrm{H}), 6.62(\mathrm{~s}, 1 \mathrm{H}), 3.81(\mathrm{dd}, J=8.0,5.0 \mathrm{~Hz}, 2 \mathrm{H}), 3.04-3.02(\mathrm{~m}, 4 \mathrm{H}), 2.91(\mathrm{~s}, 6 \mathrm{H}), 2.71(\mathrm{dd}, J=$ 8.0, 7.0 Hz, $2 \mathrm{H}), 2.33(\mathrm{~s}, 3 \mathrm{H}), 2.11-2.04(\mathrm{~m}, 2 \mathrm{H}) ;{ }^{13} \mathrm{C} \mathrm{NMR}\left(125 \mathrm{MHz}\right.$, methanol- $\left.d_{4}\right): \delta$ $163.0\left(\mathrm{~d}, J_{\mathrm{C}-\mathrm{F}}=243.0 \mathrm{~Hz}\right), 157.3,154.4,148.4,143.3\left(\mathrm{~d}, J_{\mathrm{C}-\mathrm{F}}=7.8 \mathrm{~Hz}\right), 142.7\left(\mathrm{~d}, J_{\mathrm{C}-\mathrm{F}}=7.9\right.$ $\mathrm{Hz}), 124.2\left(\mathrm{~d}, J_{\mathrm{C}-\mathrm{F}}=2.1 \mathrm{~Hz}\right), 113.7,113.0\left(\mathrm{~d}, J_{\mathrm{C}-\mathrm{F}}=21.3 \mathrm{~Hz}\right), 112.9\left(\mathrm{~d}, J_{\mathrm{C}-\mathrm{F}}=21.4 \mathrm{~Hz}\right)$, 109.5, 57.0, 42.2, 34.1, 34.0, 31.7, 25.7, 20.6; HRMS ESI: calcd. For $\mathrm{C}_{19} \mathrm{H}_{27} \mathrm{FN}_{3}[\mathrm{M}+\mathrm{H}]^{+}$, 316.2184; found, 316.2192 .

\section{6-(3-(3-(dimethylamino)propyl)-5-(trifluoromethyl)phenethyl)-4-methylpyridin-2-amine}

(13): Compound 13 was synthesized according to general procedure $C$ using 26c (146 mg, $0.3 \mathrm{mmol}), 10 \%$ wt. $\mathrm{Pd} / \mathrm{C}(16 \mathrm{mg})$, and $\mathrm{NH}_{2} \mathrm{OH} \cdot \mathrm{HCl}(63 \mathrm{mg})$. Compound $\mathbf{1 3}$ was isolated as a brown oil (128 mg, 85\%) after flash column chromatography (MeOH: DCM 3:7). ${ }^{1} \mathrm{H}$ NMR (500 MHz, methanol- $\left.d_{4}\right): \delta 7.56(\mathrm{~s}, 1 \mathrm{H}), 7.46(\mathrm{~s}, 1 \mathrm{H}), 7.41(\mathrm{~s}, 1 \mathrm{H}), 6.74(\mathrm{~s}, 1 \mathrm{H}), 6.64$ (s, 1H), $3.28-3.20(\mathrm{~m}, 2 \mathrm{H}), 3.18-3.12(\mathrm{~m}, 2 \mathrm{H}), 3.11-3.05(\mathrm{~m}, 2 \mathrm{H}), 2.94(\mathrm{~s}, 6 \mathrm{H}), 2.82(\mathrm{t}$, $J=7.9 \mathrm{~Hz}, 2 \mathrm{H}), 2.35$ (s, 3H), $2.18-2.08(\mathrm{~m}, 2 \mathrm{H}) ;{ }^{13} \mathrm{C}$ NMR $\left(125 \mathrm{MHz}\right.$, methanol- $\left.d_{4}\right): \delta$ 157.6, 154.4, 148.2, 142.1, 141.4, 132.31, 130.6 (q, $J=31.7 \mathrm{~Hz}), 124.0$ (q, $J=271.6 \mathrm{~Hz}$ ), 123.1 (m, 2C), 113.8, 109.5, 57.0, 42.2, 34.1, 34.0, 31.7, 25.8, 20.6; HRMS ESI: calcd. For $\mathrm{C}_{20} \mathrm{H}_{26} \mathrm{~F}_{3} \mathrm{~N}_{3}[\mathrm{M}+\mathrm{H}]^{+}$, 366.2151; found, 366.2163.

3-(2-(6-amino-4-methylpyridin-2-yl)ethyl)-5-(3-(dimethylamino)propyl)benzonitrile (14): Compound 14 was synthesized from $28 \mathrm{c}$ by first removing 2,5-dimethylpyrrole protecting group using $\mathrm{NH}_{2} \mathrm{OH} . \mathrm{HCl}$ in $\mathrm{EtOH} / \mathrm{H}_{2} \mathrm{O}(2: 1)$. Product $29 \mathbf{b}$ was then subjected to hydrogenation with $10 \%$ wt. $\mathrm{Pd} / \mathrm{C}$ in $\mathrm{MeOH}(0.1 \mathrm{M})$. The reaction mixture was stirred at r.t. for $20 \mathrm{~h}$ under hydrogen gas. After that, the crude was filtered and the filtrate was concentrated under reduced pressure to give a crude $\mathbf{1 4}$ which was isolated as a brown oil 
after flash column chromatography (MeOH: DCM 3:7). ${ }^{1} \mathrm{H}$ NMR (500 MHz, methanol- $\left.d_{4}\right)$ : $\delta 7.61(\mathrm{~s}, 1 \mathrm{H}), 7.60(\mathrm{~s}, 1 \mathrm{H}), 7.28(\mathrm{~s}, 1 \mathrm{H}), 6.35(\mathrm{~s}, 1 \mathrm{H}), 6.32(\mathrm{~s}, 1 \mathrm{H}), 3.04-2.98(\mathrm{~m}, 2 \mathrm{H})$, $2.96-2.91(\mathrm{~m}, 2 \mathrm{H}), 2.90-2.84(\mathrm{~m}, 2 \mathrm{H}), 2.76-2.70(\mathrm{~m}, 8 \mathrm{H}), 2.20(\mathrm{~s}, 3 \mathrm{H}), 2.05-1.95(\mathrm{~m}$, 2H).; ${ }^{13} \mathrm{C}$ NMR (125 MHz, methanol- $\left.d_{4}\right): \delta 171.1,158.9,157.2,150.4,142.2,141.1,133.9$, 131.9, 125.3, 125.1, 113.3, 106.8, 57.5, 42.6, 38.4, 35.5, 32.1, 26.6, 19.7; HRMS ESI: calcd. For $\mathrm{C}_{20} \mathrm{H}_{26} \mathrm{~N}_{4}[\mathrm{M}+\mathrm{H}]^{+}$, 323.2230; found, 323.2251.

\section{4-Methyl-6-(2-(5-(3-(methylamino)phenyl)pyridin-3-yl)ethyl)pyridin-2-amine (15):}

Compound 15 was synthesized according to general procedure F using 33a (139 mg, 0.35 $\mathrm{mmol})$ and $\mathrm{NH}_{2} \mathrm{OH} \cdot \mathrm{HCl}(86 \mathrm{mg}) .15$ was isolated as a light-yellow oil $(75.7 \mathrm{mg}, 68 \%)$ after flash column chromatography (methanol: DCM 1:4). ${ }^{1} \mathrm{H}$ NMR (500 MHz, methanol- $d_{4}$ ): $\delta$ $8.66(\mathrm{~s}, 1 \mathrm{H}), 8.46(\mathrm{~s}, 1 \mathrm{H}), 8.02(\mathrm{~s}, 1 \mathrm{H}), 7.22(\mathrm{t}, J=7.5 \mathrm{~Hz}, 1 \mathrm{H}), 7.89-6.87(\mathrm{~m}, 2 \mathrm{H}), 6.71(\mathrm{~s}$, $1 \mathrm{H}), 6.69(\mathrm{~d}, J=7.5 \mathrm{~Hz}, 1 \mathrm{H}), 6.62(\mathrm{~s}, 1 \mathrm{H}), 3.18-3.15(\mathrm{~m}, 2 \mathrm{H}), 3.10-3.07(\mathrm{~m}, 2 \mathrm{H}), 2.82(\mathrm{~s}$, $3 \mathrm{H}), 2.31(\mathrm{~s}, 3 \mathrm{H}) ;{ }^{13} \mathrm{C}$ NMR $\left(125 \mathrm{MHz}\right.$, methanol- $\left.d_{4}\right): \delta 157.5,154.5,150.6,148.0,146.7$, 144.7, 138.1, 137.4, 136.2, 135.7, 129.5, 115.2, 113.8, 112.5, 110.6, 109.7, 33.8, 31.4, 29.5, 20.6; HRMS ESI: calcd. For $\mathrm{C}_{20} \mathrm{H}_{23} \mathrm{~N}_{4}[\mathrm{M}+\mathrm{H}]^{+}, 319.1924$; found, 319.1917 .

\section{4-Methyl-6-(2-(5-(3-((methylamino)methyl)phenyl)pyridin-3-yl)ethyl)pyridin-2-amine}

(16): Compound 16 was synthesized according to general procedure F using 33b $(98.2 \mathrm{mg}$, $0.24 \mathrm{mmol})$ and $\mathrm{NH}_{2} \mathrm{OH} \cdot \mathrm{HCl}(53 \mathrm{mg}) .16$ was isolated as a light-yellow oil $(40.2 \mathrm{mg}, 51 \%)$ after flash column chromatography (methanol: DCM 1:4). ${ }^{1} \mathrm{H}$ NMR $(500 \mathrm{MHz}$, methanol$\left.d_{4}\right): \delta 8.79(\mathrm{~s}, 1 \mathrm{H}), 8.51(\mathrm{~s}, 1 \mathrm{H}), 8.30(\mathrm{~s}, 1 \mathrm{H}), 8.01(\mathrm{~s}, 1 \mathrm{H}), 7.81(\mathrm{t}, J=6.0 \mathrm{~Hz}, 1 \mathrm{H}), 7.61(\mathrm{~d}$, $J=6.0 \mathrm{~Hz}, 2 \mathrm{H}), 6.70(\mathrm{~s}, 1 \mathrm{H}), 6.69(\mathrm{~s}, 1 \mathrm{H}), 4.33(\mathrm{~s}, 2 \mathrm{H}), 3.23-3.20(\mathrm{~m}, 2 \mathrm{H}), 3.15-3.13(\mathrm{~m}$, 2H), $2.79(\mathrm{~s}, 3 \mathrm{H}), 2.34(\mathrm{~s}, 3 \mathrm{H}) ;{ }^{13} \mathrm{C}$ NMR (125 MHz, methanol- $\left.d_{4}\right): \delta 157.7,154.5,147.9$, 147.1, 144.5, 137.5, 136.8, 136.5, 136.4, 132.4, 129.8, 129.7, 128.6, 127.9, 113.8, 109.7, 52.0, 33.6, 31.9, 31.3, 20.6; HRMS ESI: calcd. For $\mathrm{C}_{21} \mathrm{H}_{25} \mathrm{~N}_{4}[\mathrm{M}+\mathrm{H}]^{+}$, 333.2074; found, 333.2081 .

\section{4-Methyl-6-(2-(5-(4-((methylamino)methyl)phenyl)pyridin-3-yl)ethyl)pyridin-2-amine}

(17): Compound 17 was synthesized according to general procedure $F$ using 33c $(109.7 \mathrm{mg}$, $0.27 \mathrm{mmol})$ and $\mathrm{NH}_{2} \mathrm{OH} \cdot \mathrm{HCl}(59 \mathrm{mg}) .17$ was isolated as a light-yellow oil $(85.2 \mathrm{mg}, 95 \%)$ after flash column chromatography (methanol: DCM 1:3). ${ }^{1} \mathrm{H}$ NMR $(500 \mathrm{MHz}$, methanol$\left.d_{4}\right): \delta 8.70(\mathrm{~s}, 1 \mathrm{H}), 8.46(\mathrm{~s}, 1 \mathrm{H}), 8.12(\mathrm{~s}, 1 \mathrm{H}), 7.80(\mathrm{~d}, J=8.0 \mathrm{~Hz}, 2 \mathrm{H}), 7.68(\mathrm{~d}, J=8.0 \mathrm{~Hz}$, $2 \mathrm{H}), 6.69(\mathrm{~s}, 1 \mathrm{H}), 6.65(\mathrm{~s}, 1 \mathrm{H}), 5.87(\mathrm{~s}, 2 \mathrm{H}), 4.28(\mathrm{~s}, 2 \mathrm{H}), 3.20-3.17(\mathrm{~m}, 2 \mathrm{H}), 3.13-3.10(\mathrm{~m}$, 2H), 2.77 (s, 3H), $2.33(\mathrm{~s}, 3 \mathrm{H}) ;{ }^{13} \mathrm{C}$ NMR (125 MHz, methanol- $\left.d_{4}\right): \delta 157.5,154.6,148.1$, 147.9, 145.2, 138.2, 136.4, 136.1, 135.5, 131.4, 130.5, 127.6, 113.7, 109.6, 51.7, 33.7, 31.9, 31.4, 20.5; HRMS ESI: calcd. For $\mathrm{C}_{21} \mathrm{H}_{25} \mathrm{~N}_{4}[\mathrm{M}+\mathrm{H}]^{+}$, 333.2074; found, 333.2070.

6-(2-(5-Fluoro-3'-((methylamino)methyl)-[1,1'-biphenyl]-3-yl)ethyl)-4-methylpyridin-2amine (18): Compound 18 was synthesized according to general procedure $\mathrm{F}$ using 35a $(141.9 \mathrm{mg}, 0.33 \mathrm{mmol})$ and $\mathrm{NH}_{2} \mathrm{OH} \cdot \mathrm{HCl}(72 \mathrm{mg}) . \mathbf{1 8}$ was isolated as a brown yellow oil (92.8 mg, 80\%) after flash column chromatography (methanol: DCM 1:4). ${ }^{1} \mathrm{H}$ NMR (500 MHz, methanol- $\left.d_{4}\right): \delta 7.90(\mathrm{~s}, 1 \mathrm{H}), 7.72(\mathrm{~d}, J=7.5 \mathrm{~Hz}, 1 \mathrm{H}), 7.57-7.50(\mathrm{~m}, 3 \mathrm{H}), 7.30(\mathrm{~d}, J=$ $9.5 \mathrm{~Hz}, 1 \mathrm{H}), 7.05(\mathrm{~d}, J=9.5 \mathrm{~Hz}, 1 \mathrm{H}), 6.67(\mathrm{~s}, 1 \mathrm{H}), 6.65(\mathrm{~s}, 1 \mathrm{H}), 4.29(\mathrm{~s}, 2 \mathrm{H}), 3.15-3.12(\mathrm{~m}$, $2 \mathrm{H}), 3.11-3.08(\mathrm{~m}, 2 \mathrm{H}), 2.77$ (s, 3H), 2.33 (s, 3H); ${ }^{13} \mathrm{C} \mathrm{NMR}$ (125 MHz, methanol- $\left.d_{4}\right): \delta$ 
$163.4\left(\mathrm{~d}, J_{\mathrm{C}-\mathrm{F}}=243.8 \mathrm{~Hz}\right), 157.7,154.4,148.3,143.1\left(\mathrm{~d}, J_{\mathrm{C}-\mathrm{F}}=7.5 \mathrm{~Hz}\right), 142.5\left(\mathrm{~d}, J_{\mathrm{C}-\mathrm{F}}=8.8\right.$ $\mathrm{Hz}), 140.5,132.0,129.5,129.0,128.4,127.8,123.0,114.2\left(\mathrm{~d}, J_{\mathrm{C}-\mathrm{F}}=21.3 \mathrm{~Hz}\right), 113.7,111.5$ $\left(\mathrm{d}, J_{\mathrm{C}-\mathrm{F}}=22.5 \mathrm{~Hz}\right), 109.5,52.1,34.2,34.0,31.9,20.6$; HRMS ESI: calcd. For $\mathrm{C}_{22} \mathrm{H}_{25} \mathrm{FN}_{3}$ $[\mathrm{M}+\mathrm{H}]^{+}, 350.2030$; found, 350.2030.

6-(2-(5-Fluoro-4' '-((methylamino)methyl)-[1,1'-biphenyl]-3-yl)ethyl)-4-methylpyridin-2amine (19): Compound 19 was synthesized according to general procedure $F$ using $35 \mathrm{~b}$ (127.5 mg, $0.30 \mathrm{mmol})$ and $\mathrm{NH}_{2} \mathrm{OH} \cdot \mathrm{HCl}(65 \mathrm{mg}) .19$ was isolated as a brown yellow oil (89 $\mathrm{mg}, 85 \%$ ) after flash column chromatography (methanol: DCM 1:4). ${ }^{1} \mathrm{H}$ NMR (500 MHz, methanol- $\left.d_{4}\right): \delta 7.71(\mathrm{~d}, J=8.0 \mathrm{~Hz}, 2 \mathrm{H}), 7.62(\mathrm{~d}, J=8.0 \mathrm{~Hz}, 2 \mathrm{H}), 7.40(\mathrm{~s}, 1 \mathrm{H}), 7.23(\mathrm{~d}, J=9.5$ $\mathrm{Hz}, 1 \mathrm{H}), 7.06(\mathrm{~d}, J=9.5 \mathrm{~Hz}, 1 \mathrm{H}), 6.68(\mathrm{~s}, 1 \mathrm{H}), 6.62(\mathrm{~s}, 1 \mathrm{H}), 4.26(\mathrm{~s}, 2 \mathrm{H}), 3.14-3.11(\mathrm{~m}, 2 \mathrm{H})$, 3.08-3.05 (m, 2H), $2.76(\mathrm{~s}, 3 \mathrm{H}), 2.32(\mathrm{~s}, 3 \mathrm{H}) ;{ }^{13} \mathrm{C}$ NMR (125 MHz, methanol- $\left.d_{4}\right): \delta 161.8$ $\left(\mathrm{d}, J_{\mathrm{C}-\mathrm{F}}=243.8 \mathrm{~Hz}\right), 156.1,152.9,146.7,141.6\left(\mathrm{~d}, J_{\mathrm{C}-\mathrm{F}}=7.5 \mathrm{~Hz}\right), 140.9\left(\mathrm{~d}, J_{\mathrm{C}-\mathrm{F}}=8.8 \mathrm{~Hz}\right)$, $139.2\left(\mathrm{~d}, J_{\mathrm{C}-\mathrm{F}}=1.3 \mathrm{~Hz}\right), 129.4,128.8,125.9,121.3\left(\mathrm{~d}, J_{\mathrm{C}-\mathrm{F}}=2.5 \mathrm{~Hz}\right), 112.7\left(\mathrm{~d}, J_{\mathrm{C}-\mathrm{F}}=21.3\right.$ $\mathrm{Hz}), 112.2,110.0\left(\mathrm{~d}, J_{\mathrm{C}-\mathrm{F}}=22.5 \mathrm{~Hz}\right), 108.0,50.3,32.7,32.5,30.3,19.1$; HRMS ESI: calcd. For $\mathrm{C}_{22} \mathrm{H}_{25} \mathrm{FN}_{3}[\mathrm{M}+\mathrm{H}]^{+}$, 350.2030; found, 350.2030.

tert-Butyl-3-(3-(2-(6-(2,5-dimethyl-1H-pyrrol-1-yl)-4-methylpyridin-2yl)ethyl)phenyl)prop-2-ynyl(methyl)carbamate (24a): Compound 24a was synthesized according to general procedure A using $\mathrm{Pd}\left(\mathrm{PPh}_{3}\right)_{4}(28.8 \mathrm{mg}), \mathrm{CuI}(4.7 \mathrm{mg})$, alkyne 23a (126.8 $\mathrm{mg}, 0.75 \mathrm{mmol})$, and 22a (184.3 $\mathrm{mg}, 0.50 \mathrm{mmol})$. 24a was isolated as a yellow oil (70.2 mg, 31\%) after flash column chromatography (ethyl acetate: hexanes 1:4). ${ }^{1} \mathrm{H}$ NMR $\left(500 \mathrm{MHz}, \mathrm{CDCl}_{3}\right): \delta 7.24-7.21(\mathrm{~m}, 2 \mathrm{H}), 7.17(\mathrm{t}, J=7.5 \mathrm{~Hz}, 1 \mathrm{H}), 7.09(\mathrm{~d}, J=7.5 \mathrm{~Hz}, 1 \mathrm{H})$, $6.87(\mathrm{~s}, 1 \mathrm{H}), 6.83(\mathrm{~s}, 1 \mathrm{H}), 5.87(\mathrm{~s}, 2 \mathrm{H}), 4.25$ (brs, $2 \mathrm{H}), 3.05-3.02(\mathrm{~m}, 4 \mathrm{H}), 2.95(\mathrm{~s}, 3 \mathrm{H}), 2.34$ (s, 3H), 2.10 (s, 6H), 1.47 (s, 9H); ${ }^{13} \mathrm{C}$ NMR (125 MHz, $\left.\mathrm{CDCl}_{3}\right): \delta 160.6,155.3,151.7$, 149.5, 141.6, 131.8, 129.4, 128.6, 128.5, 128.3, 122.8, 122.6, 120.2, 106.7, 84.4, 83.7, 80.1, $39.5,35.5,33.5,28.4,28.3,21.0,13.2$.

tert-Butyl-3-(3-(2-(6-(2,5-dimethyl-1H-pyrrol-1-yl)-4-methylpyridin-2-yl)ethyl)-5fluorophenyl)prop-2-ynyl(methyl)carbamate (24b): Compound 24b was synthesized according to general procedure A using $\mathrm{Pd}\left(\mathrm{PPh}_{3}\right)_{4}(28.8 \mathrm{mg}), \mathrm{CuI}(4.9 \mathrm{mg})$, alkyne 23a (125.6 mg), and 22b (193.1 mg, $0.50 \mathrm{mmol}) .24 \mathbf{b}$ was isolated as a yellow oil (139.2 mg, $60 \%$ ) after flash column chromatography (ethyl acetate: hexanes 3:7). ${ }^{1} \mathrm{H}$ NMR $(500 \mathrm{MHz}$, $\left.\mathrm{CDCl}_{3}\right): \delta 7.02(\mathrm{~s}, 1 \mathrm{H}), 6.91(\mathrm{~d}, J=9.0 \mathrm{~Hz}, 1 \mathrm{H}), 6.88(\mathrm{~s}, 1 \mathrm{H}), 6.84(\mathrm{~s}, 1 \mathrm{H}), 6.81(\mathrm{~d}, J=9.5$ $\mathrm{Hz}, 1 \mathrm{H}), 5.86(\mathrm{~s}, 2 \mathrm{H}), 4.24$ (brs, 2H), 3.04-3.02 (m, 4H), $2.94(\mathrm{~s}, 3 \mathrm{H}), 2.35(\mathrm{~s}, 3 \mathrm{H}), 2.10(\mathrm{~s}$, $6 \mathrm{H}), 1.47(\mathrm{~s}, 9 \mathrm{H}) ;{ }^{13} \mathrm{C} \mathrm{NMR}\left(125 \mathrm{MHz}, \mathrm{CDCl}_{3}\right): \delta 162.4\left(\mathrm{~d}, J_{\mathrm{C}-\mathrm{F}}=244.5 \mathrm{~Hz}\right), 160.1,155.3$, $151.7,149.6,144.1\left(\mathrm{~d}, J_{\mathrm{C}-\mathrm{F}}=7.5 \mathrm{~Hz}\right), 128.5,127.8\left(\mathrm{~d}, J_{\mathrm{C}-\mathrm{F}}=2.4 \mathrm{~Hz}\right), 124.4\left(\mathrm{~d}, J_{\mathrm{C}-\mathrm{F}}=10.0\right.$ $\mathrm{Hz}), 122.7,120.3,116.1\left(\mathrm{~d}, J_{\mathrm{C}-\mathrm{F}}=22.9 \mathrm{~Hz}\right), 115.8\left(\mathrm{~d}, J_{\mathrm{C}-\mathrm{F}}=21.0 \mathrm{~Hz}\right), 106.7,85.4,82.5(\mathrm{~d}$, $\left.J_{\mathrm{C}-\mathrm{F}}=3.4 \mathrm{~Hz}\right), 80.2,39.0,35.1,35.0,33.6,28.4,21.0,13.2$. MS ESI $[\mathrm{M}+\mathrm{Na}]^{+}=498.21$.

tert-Butyl(3-(3-(2-(6-(2,5-dimethyl-1H-pyrrol-1-yl)-4-methylpyridin-2-yl)ethyl)-5(trifluoromethyl)phenyl)prop-2-yn-1-yl)(methyl)carbamate (24c): Compound 24c was synthesized according to general procedure A using $\mathrm{Pd}\left(\mathrm{PPh}_{3}\right)_{4}(29.1 \mathrm{mg}), \mathrm{CuI}(5.0 \mathrm{mg})$, alkyne 23a (131.0 mg), and 22c (198.1 mg, $0.50 \mathrm{mmol})$. 24c was isolated as a yellow oil (222 mg, 85\%) after flash column chromatography (ethyl acetate: hexanes 1:4). ${ }^{1} \mathrm{H}$ NMR 
(500 MHz, $\left.\mathrm{CDCl}_{3}\right): \delta 7.48(\mathrm{~s}, 1 \mathrm{H}), 7.41(\mathrm{~s}, 1 \mathrm{H}), 7.27(\mathrm{~s}, 1 \mathrm{H}), 6.86(\mathrm{~s}, 2 \mathrm{H}), 5.88(\mathrm{~s}, 2 \mathrm{H}), 4.26$ (brs, 2H), 3.12-3.09 (m, 2H), 3.08-3.05 (m, 2H), 2.97 (s, 3H), 2.35 (s, 3H), $2.10(\mathrm{~s}, 6 \mathrm{H}), 1.48$ (s, 9H); ${ }^{13} \mathrm{C}$ NMR $\left(125 \mathrm{MHz}, \mathrm{CDCl}_{3}\right): \delta 159.8,155.3,151.8,149.7,142.7,135.0,130.8(\mathrm{q}$, $\left.J_{\mathrm{C}-\mathrm{F}}=32.5 \mathrm{~Hz}\right), 128.4,126.2\left(\mathrm{~d}, J_{\mathrm{C}-\mathrm{F}}=3.1 \mathrm{~Hz}\right), 125.1\left(\mathrm{~d}, J_{\mathrm{C}-\mathrm{F}}=3.8 \mathrm{~Hz}\right), 123.8,123.7(\mathrm{q}$, $\left.J_{\mathrm{C}-\mathrm{F}}=271.3 \mathrm{~Hz}\right), 122.8,120.4,106.8,86.1,82.2,80.2,39.1,35.1,33.6,28.4,20.9,13.2 . \mathrm{MS}$ $\mathrm{ESI}[\mathrm{M}+\mathrm{Na}]^{+}=548.20$

3-(3-(2-(6-(2,5-Dimethyl-1H-pyrrol-1-yl)-4-methylpyridin-2-yl)ethyl)phenyl)-N,Ndimethylprop-2-yn-1-amine (26a): Compound 26a was synthesized according to general procedure A using $\mathrm{Pd}\left(\mathrm{PPh}_{3}\right)_{4}(28.8 \mathrm{mg}), \mathrm{CuI}(5.0 \mathrm{mg})$, alkyne 23b $(128.9 \mathrm{mg})$, and 22a (184.4 mg, $0.50 \mathrm{mmol})$. 26a was isolated as a brown oil $(89.4 \mathrm{mg}, 48 \%)$ after flash column chromatography (ethyl acetate: hexanes 6:4). ${ }^{1} \mathrm{H}$ NMR $\left(500 \mathrm{MHz}, \mathrm{CDCl}_{3}\right): \delta 7.26-7.24(\mathrm{~m}$, $2 \mathrm{H}), 7.17(\mathrm{t}, J=7.5 \mathrm{~Hz}, 1 \mathrm{H}), 7.09(\mathrm{~d}, J=7.5 \mathrm{~Hz}, 1 \mathrm{H}), 6.87(\mathrm{~s}, 1 \mathrm{H}), 6.84(\mathrm{~s}, 1 \mathrm{H}), 5.87(\mathrm{~s}$, $2 \mathrm{H}), 3.44(\mathrm{~s}, 2 \mathrm{H}), 3.06-3.01(\mathrm{~m}, 4 \mathrm{H}), 2.35(\mathrm{~s}, 6 \mathrm{H}), 2.34(\mathrm{~s}, 3 \mathrm{H}), 2.10(\mathrm{~s}, 6 \mathrm{H}) ;{ }^{13} \mathrm{C} \mathrm{NMR}(125$ $\left.\mathrm{MHz}, \mathrm{CDCl}_{3}\right): \delta 160.7,151.7,149.5,141.6,131.8,129.3,128.5,128.4,128.3,123.2,122.7$, $120.1,106.7,85.4,84.4,48.6,44.3,39.5,35.5,21.0,13.2$.

3-(3-(2-(6-(2,5-Dimethyl-1H-pyrrol-1-yl)-4-methylpyridin-2-yl)ethyl)-5-fluorophenyl)$\mathrm{N}, \mathrm{N}$-dimethylprop-2-yn-1-amine (26b): Compound 26b was synthesized according to general procedure A using $\mathrm{Pd}\left(\mathrm{PPh}_{3}\right)_{4}(28.9 \mathrm{mg}), \mathrm{CuI}(5.1 \mathrm{mg})$, alkyne $\mathbf{2 3 b}(125.8 \mathrm{mg})$, and 22b (193.0 mg, $0.50 \mathrm{mmol})$. 26b was isolated as a brown oil (189.5 mg, 97\%) after flash column chromatography (Methanol: DCM 1:19). ${ }^{1} \mathrm{H}$ NMR (500 MHz, $\mathrm{CDCl}_{3}$ ): $\delta 7.03$ (s, $1 \mathrm{H}), 6.93(\mathrm{~d}, J=9.0 \mathrm{~Hz}, 1 \mathrm{H}), 6.87(\mathrm{~s}, 1 \mathrm{H}), 6.84(\mathrm{~s}, 1 \mathrm{H}), 6.80(\mathrm{~d}, J=9.5 \mathrm{~Hz}, 1 \mathrm{H}), 5.87(\mathrm{~s}$, 2H), 3.43 (s, 2H), 3.04-3.02 (m, 4H), 2.35 (s, 3H), 2.34 (s, 6H), 2.10 (s, 6H); ${ }^{13} \mathrm{C}$ NMR (125 $\left.\mathrm{MHz}, \mathrm{CDCl}_{3}\right): \delta 162.4\left(\mathrm{~d}, J_{\mathrm{C}-\mathrm{F}}=244.4 \mathrm{~Hz}\right), 160.2,151.8,149.6,144.1\left(\mathrm{~d}, J_{\mathrm{C}-\mathrm{F}}=8.0 \mathrm{~Hz}\right)$, $128.5,127.8\left(\mathrm{~d}, J_{\mathrm{C}-\mathrm{F}}=2.4 \mathrm{~Hz}\right), 124.7\left(\mathrm{~d}, J_{\mathrm{C}-\mathrm{F}}=10.0 \mathrm{~Hz}\right), 122.7,120.3,116.1\left(\mathrm{~d}, J_{\mathrm{C}-\mathrm{F}}=22.8\right.$ $\mathrm{Hz}), 115.5\left(\mathrm{~d}, J_{\mathrm{C}-\mathrm{F}}=21.0 \mathrm{~Hz}\right), 106.8,85.4,84.3\left(\mathrm{~d}, J_{\mathrm{C}-\mathrm{F}}=3.4 \mathrm{~Hz}\right), 48.5,44.3,39.1,35.1$, 21.0, 13.2. MS ESI $[\mathrm{M}+\mathrm{H}]^{+}=390.23$

3-(3-(2-(6-(2,5-dimethyl-1H-pyrrol-1-yl)-4-methylpyridin-2-yl)ethyl)-5(trifluoromethyl)phenyl)-N,N-dimethylprop-2-yn-1-amine (26c): Compound 26c was synthesized according to general procedure A using $\mathrm{Pd}\left(\mathrm{PPh}_{3}\right)_{4}(28.8 \mathrm{mg}), \mathrm{CuI}(5 \mathrm{mg})$, alkyne 23b (128.9 mg), and 22c (218 $\mathrm{mg}, 0.50 \mathrm{mmol})$. 26c was isolated as a brown oil (132 $\mathrm{mg}, 60 \%)$ after flash column chromatography (Methanol: DCM 1:19). ${ }^{1} \mathrm{H}$ NMR (500 MHz, $\left.\mathrm{CDCl}_{3}\right): \delta 7.32(\mathrm{~s}, 1 \mathrm{H}), 7.24(\mathrm{~d}, J=1.5 \mathrm{~Hz}, 1 \mathrm{H}), 7.09(\mathrm{~d}, J=2.0 \mathrm{~Hz}, 1 \mathrm{H}), 6.68(\mathrm{~s}, 1 \mathrm{H}), 6.67$ (s, 1H), $5.70(\mathrm{~s}, 2 \mathrm{H}), 3.28(\mathrm{~s}, 2 \mathrm{H}), 2.97-2.84(\mathrm{~m}, 4 \mathrm{H}), 2.18(\mathrm{~s}, 6 \mathrm{H}), 2.17(\mathrm{~s}, 3 \mathrm{H}), 1.93(\mathrm{~s}$, $6 \mathrm{H}) ;{ }^{13} \mathrm{C} \mathrm{NMR}\left(125 \mathrm{MHz}, \mathrm{CDCl}_{3}\right): \delta \delta 171.1,159.9,151.8,149.6,142.6,134.9,130.8$ (q, $\left.J_{\mathrm{C}-\mathrm{F}}=32.3 \mathrm{~Hz}\right), 128.4,126.2\left(\mathrm{q}, J_{\mathrm{C}-\mathrm{F}}=3.8 \mathrm{~Hz}\right), 124.85\left(\mathrm{q}, J_{\mathrm{C}-\mathrm{F}}=3.8 \mathrm{~Hz}\right), 124.8,124.1$, $122.8,120.4,106.8,86.1,84.0,48.5,44.3,39.1,35.1,20.9,13.2$.

tert-Butyl N-(3-(3-cyano-5-(2-(6-(2,5-dimethyl-1H-pyrrol-1-yl)-4-methylpyridin-2yl)ethyl)phenyl)prop-2-yn-1-yl)(methyl)carbamate (28a): Compound 28a was synthesized according to general procedure A using $\mathrm{Pd}\left(\mathrm{PPh}_{3}\right)_{4}(28.8 \mathrm{mg}), \mathrm{CuI}(4.0 \mathrm{mg})$, alkyne 23a (112 $\mathrm{mg}$ ) and 27 (191 mg, $0.5 \mathrm{mmol})$. 28a was isolated as a brown oil (183.7 mg, 75\%) after flash column chromatography (MeOH: DCM 1:19). ${ }^{1} \mathrm{H}$ NMR (500 MHz, $\left.\mathrm{CDCl}_{3}\right): \delta 7.47$ (s, 
1H), $7.42(\mathrm{~s}, 1 \mathrm{H}), 7.33(\mathrm{~s}, 1 \mathrm{H}), 6.86(\mathrm{~s}, 1 \mathrm{H}), 6.85(\mathrm{~s}, 1 \mathrm{H}), 5.86(\mathrm{~s}, 2 \mathrm{H}), 4.24$ (brs, 2H), 3.08-3.02 (m, 4H), 2.93 (s, 3H), 2.34 (s, 3H), 2.08 (s, 6H), 1.46 (s, 9H); ${ }^{13} \mathrm{C}$ NMR (125 $\left.\mathrm{MHz}, \mathrm{CDCl}_{3}\right): \delta 159.5,155.3,151.8,149.8,143.2,136.1,132.7,131.5,128.4,124.4,122.7$, $120.5,118.1,112.7,106.8,87.1,81.4,80.3,38.8,34.8,34.7,33.7,28.4,20.9,13.2$. MS ESI $[\mathrm{M}+\mathrm{Na}]^{+}=505.21$

3-(2-(6-(2,5-dimethyl-1H-pyrrol-1-yl)-4-methylpyridin-2-yl)ethyl)-5-(3(dimethylamino)prop-1-yn-1-yl)benzonitrile (28c): Compound 28c was synthesized according to general procedure A using $\mathrm{Pd}\left(\mathrm{PPh}_{3}\right)_{4}(28.8 \mathrm{mg}), \mathrm{CuI}(4.0 \mathrm{mg})$, alkyne 23b (128.9 mg), and 27 (191 mg, $0.5 \mathrm{mmol}) .28 \mathrm{c}$ was isolated as a brown oil (148 $\mathrm{mg}, 75 \%)$ after flash column chromatography (MeOH: DCM 1:19). ${ }^{1} \mathrm{H}$ NMR (500 MHz, $\mathrm{CDCl}_{3}$ ): $\delta{ }^{1} \mathrm{H}$ NMR (500 MHz, Chloroform-d) $\delta 7.30$ (s, 1H), 7.24 (s, 1H), $7.14(\mathrm{~s}, 1 \mathrm{H}), 6.68(\mathrm{~s}, 1 \mathrm{H}), 6.66$ (s, 1H), 5.67 (s, 2H), $3.24(\mathrm{~s}, 2 \mathrm{H}), 2.93-2.80(\mathrm{~m}, 4 \mathrm{H}), 2.16(\mathrm{~s}, 3 \mathrm{H}), 2.14(\mathrm{~s}, 6 \mathrm{H}), 1.89(\mathrm{~s}$, $6 \mathrm{H}) ;{ }^{13} \mathrm{C} \mathrm{NMR}\left(125 \mathrm{MHz}, \mathrm{CDCl}_{3}\right): \delta 159.6,151.8,149.8,143.2,136.1,132.7,131.3,128.4$, $124.7,122.7,120.5,118.2,112.6,106.8,87.2,83.2,48.5,44.3,38.8,34.7,21.0,13.2$.

3-(5-(2-(6-(2,5-Dimethyl-1H-pyrrol-1-yl)-4-methylpyridin-2-yl)ethyl)pyridin-3-yl)-Nmethylaniline (33a): Compound 33a was prepared via Suzuki cross-coupling and Boc deprotection. 32a was synthesized according to general procedure D using $\mathrm{Pd}\left(\mathrm{PPh}_{3}\right)_{4}(24.1$ $\mathrm{mg}), \mathrm{K}_{2} \mathrm{CO}_{3}(141 \mathrm{mg})$, boronic acid $\mathbf{3 1 a}(172.6 \mathrm{mg})$, and $\mathbf{3 0}(149 \mathrm{mg}, 0.4 \mathrm{mmol})$. Reaction product 32a was diluted with DCM to form a $0.1 \mathrm{M}$ solution followed by addition of TFA ( $20 \%$ volume). The reaction mixture was allowed to stir at r.t. for $1 \mathrm{~h}$. At this time, the crude product was concentrated under reduced pressure, diluted with DCM, and washed with sat. $\mathrm{NaHCO}_{3}$. The organic layer was dried over $\mathrm{Na}_{2} \mathrm{SO}_{4}$ and concentrated to give crude product. 33a was isolated as a light-yellow oil (139 mg, 70\%) after flash column chromatography (methanol: DCM 1:19). ${ }^{1} \mathrm{H}$ NMR (500 MHz, $\left.\mathrm{CDCl}_{3}\right): \delta 8.65(\mathrm{~s}, 1 \mathrm{H}), 8.37(\mathrm{~s}, 1 \mathrm{H}), 7.25(\mathrm{t}, J$ $=7.5 \mathrm{~Hz}, 1 \mathrm{H}), 7.65(\mathrm{~s}, 1 \mathrm{H}), 6.90(\mathrm{~s}, 1 \mathrm{H}), 6.86(\mathrm{~s}, 1 \mathrm{H}), 6.83(\mathrm{~d}, J=7.5 \mathrm{~Hz}, 1 \mathrm{H}), 6.71(\mathrm{~s}, 1 \mathrm{H})$, $6.62(\mathrm{~d}, J=7.5 \mathrm{~Hz}, 1 \mathrm{H}), 5.88$ (s, 2H), 3.94 (brs, 1H), 3.14-3.12 (m, 4H), 2.87 (s, 3H), 2.34 (s, 3H), 2.10 (s, 6H); ${ }^{13} \mathrm{C}$ NMR (125 MHz, $\mathrm{CDCl}_{3}$ ): $\delta 160.1,151.8,149.9,149.7,148.3$, 146.0, 138.8, 136.9, 136.6, 134.7, 128.6, 128.5, 122.8, 120.4, 116.1, 112.2, 110.8, 106.8, $39.2,32.7,30.7,21.0,13.3$. MS ESI $[\mathrm{M}+\mathrm{Na}]^{+}=419.26$.

\section{1-(3-(5-(2-(6-(2,5-Dimethyl-1H-pyrrol-1-yl)-4-methylpyridin-2-yl)ethyl)pyridin-3-}

$y$ l)phenyl)-N-methylmethanamine (33b): Compound 33b was prepared via Suzuki crosscoupling and reductive amination. 32b was synthesized according to general procedure $\mathrm{D}$ using $\mathrm{Pd}\left(\mathrm{PPh}_{3}\right)_{4}(29.1 \mathrm{mg}), \mathrm{K}_{2} \mathrm{CO}_{3}$ (143 mg), boronic acid 31b (112.6 mg), and $\mathbf{3 0}$ (185 mg, $0.5 \mathrm{mmol}$ ). 33b was synthesized according to general procedure E using $\mathrm{N}$-methylamine hydrochloride (103 mg), $\mathrm{NaOAc}(125 \mathrm{mg}), \mathbf{3 2 b}$, and $\mathrm{NaBH}_{4}(116 \mathrm{mg})$. 33b was isolated as a light-yellow oil ( $98.2 \mathrm{mg}, 48 \%$ ) after flash column chromatography (methanol: DCM 1: 9). ${ }^{1} \mathrm{H}$ NMR (500 MHz, $\left.\mathrm{CDCl}_{3}\right): \delta 8.65(\mathrm{~s}, 1 \mathrm{H}), 8.36(\mathrm{~s}, 1 \mathrm{H}), 7.66(\mathrm{~s}, 1 \mathrm{H}), 7.51(\mathrm{~s}, 1 \mathrm{H}), 7.40$ $(\mathrm{d}, J=5.0 \mathrm{~Hz}, 2 \mathrm{H}), 7.34(\mathrm{t}, J=5.0 \mathrm{~Hz}, 1 \mathrm{H}), 6.89(\mathrm{~s}, 1 \mathrm{H}), 6.85(\mathrm{~s}, 1 \mathrm{H}), 5.86(\mathrm{~s}, 2 \mathrm{H}), 3.82(\mathrm{~s}$, 2H), 3.13-3.12 (m, 4H), 2.47 (s, 3H), 2.34 (s, 3H), 2.08 (s, 6H); ${ }^{13} \mathrm{C}$ NMR (125 MHz, $\left.\mathrm{CDCl}_{3}\right): \delta 160.1,151.8,149.7,148.6,146.1,140.1,138.0,136.6,136.1,134.6,129.2,128.4$, $128.1,127.1,126.0,122.8,120.4,106.8,55.6,39.2,35.7,32.7,21.0,13.2$. 
1-(4-(5-(2-(6-(2,5-Dimethyl-1H-pyrrol-1-yl)-4-methylpyridin-2-yl)ethyl)pyridin-3yl)phenyl)- $N$-methylmethanamine (33c): Compound 33c was prepared via Suzuki crosscoupling and reductive amination. 32c was synthesized according to general procedure $\mathrm{D}$ using $\mathrm{Pd}\left(\mathrm{PPh}_{3}\right)_{4}(29.3 \mathrm{mg}), \mathrm{K}_{2} \mathrm{CO}_{3}(142 \mathrm{mg})$, boronic acid 31c $(111.6 \mathrm{mg})$, and 30 (188 mg, $0.5 \mathrm{mmol}$ ). 33c was synthesized according to general procedure E using $N$-methylamine hydrochloride (105 mg), $\mathrm{NaOAc}(127 \mathrm{mg}), \mathbf{3 2 c}$, and $\mathrm{NaBH}_{4}(119 \mathrm{mg}) .33 \mathrm{c}$ was isolated as a light-yellow oil (109.7 mg, 53\%) after flash column chromatography (methanol: DCM 1: 9). ${ }^{1} \mathrm{H}$ NMR (500 MHz, $\mathrm{CDCl}_{3}$ ): $\delta 8.64(\mathrm{~s}, 1 \mathrm{H}), 8.37$ (s, 1H), 7.62 (s, $\left.1 \mathrm{H}\right), 7.46(\mathrm{~d}, J=8.0$ $\mathrm{Hz}, 2 \mathrm{H}), 7.40(\mathrm{~d}, J=8.0 \mathrm{~Hz}, 2 \mathrm{H}), 6.88(\mathrm{~s}, 1 \mathrm{H}), 6.85(\mathrm{~s}, 1 \mathrm{H}), 5.87(\mathrm{~s}, 2 \mathrm{H}), 3.79(\mathrm{~s}, 2 \mathrm{H})$, 3.13-3.11 (m, 4H), 2.46 (s, 3H), $2.33(\mathrm{~s}, 3 \mathrm{H}), 2.09(\mathrm{~s}, 6 \mathrm{H}) ;{ }^{13} \mathrm{C} \mathrm{NMR}\left(125 \mathrm{MHz}, \mathrm{CDCl}_{3}\right): \delta$ $160.0,151.8,149.7,148.5,146.0,139.9,136.6,136.5,136.0,134.4,128.9,128.4,127.1$, $122.8,120.3,106.8,55.5,39.2,35.9,32.7,21.0,13.2$.

1-(3'-(2-(6-(2,5-Dimethyl-1H-pyrrol-1-yl)-4-methylpyridin-2-yl)ethyl)-5'-fluoro-[1,1'biphenyl]-3-yl)-N-methylmethanamine (35a): Compound 35a was prepared via Suzuki cross-coupling and reductive amination. 34a was synthesized according to general procedure D using $\mathrm{Pd}\left(\mathrm{PPh}_{3}\right)_{4}(28.8 \mathrm{mg}), \mathrm{K}_{2} \mathrm{CO}_{3}$ (139 mg), boronic acid 31b (113.6 mg), and $\mathbf{3 0}$ (186 $\mathrm{mg}, 0.5 \mathrm{mmol}$ ). 35a was synthesized according to general procedure E using $N$-methylamine hydrochloride (107 mg), $\mathrm{NaOAc}(131 \mathrm{mg}), 34 \mathbf{a}$, and $\mathrm{NaBH}_{4}(121 \mathrm{mg})$. 35a was isolated as a light-yellow oil (141.9 mg, 66\%) after flash column chromatography (methanol: DCM 1: 9). ${ }^{1} \mathrm{H}$ NMR (500 MHz, $\left.\mathrm{CDCl}_{3}\right): \delta 7.50(\mathrm{~s}, 1 \mathrm{H}), 7.40(\mathrm{~d}, J=8.0 \mathrm{~Hz}, 1 \mathrm{H}), 7.37(\mathrm{t}, J=7.5 \mathrm{~Hz}$, $1 \mathrm{H}), 7.32(\mathrm{~d}, J=8.0 \mathrm{~Hz}, 1 \mathrm{H}), 7.19$ (s, 1H), $7.11(\mathrm{~d}, J=7.5 \mathrm{~Hz}, 1 \mathrm{H}), 6.92(\mathrm{~s}, 1 \mathrm{H}), 6.86(\mathrm{~s}, 1 \mathrm{H})$, $6.85(\mathrm{~d}, J=7.5 \mathrm{~Hz}, 1 \mathrm{H}), 5.88(\mathrm{~s}, 2 \mathrm{H}), 3.81(\mathrm{~s}, 2 \mathrm{H}), 3.12-3.11(\mathrm{~m}, 4 \mathrm{H}), 2.48(\mathrm{~s}, 3 \mathrm{H}), 2.36(\mathrm{~s}$, $3 \mathrm{H}), 2.11(\mathrm{~s}, 6 \mathrm{H}) ;{ }^{13} \mathrm{C} \mathrm{NMR}\left(125 \mathrm{MHz}, \mathrm{CDCl}_{3}\right): \delta 163.2\left(\mathrm{~d}, J_{\mathrm{C}-\mathrm{F}}=242.3 \mathrm{~Hz}\right), 160.5,151.8$, $149.6,144.3\left(\mathrm{~d}, J_{\mathrm{C}-\mathrm{F}}=7.5 \mathrm{~Hz}\right), 143.1\left(\mathrm{~d}, J_{\mathrm{C}-\mathrm{F}}=8.8 \mathrm{~Hz}\right), 140.2\left(\mathrm{~d}, J_{\mathrm{C}-\mathrm{F}}=2.5 \mathrm{~Hz}\right), 140.1$, $129.0,128.5,127.8,127.0,125.9,123.1\left(\mathrm{~d}, J_{\mathrm{C}-\mathrm{F}}=1.3 \mathrm{~Hz}\right), 122.7,120.3,114.1\left(\mathrm{~d}, J_{\mathrm{C}-\mathrm{F}}=\right.$ $21.3 \mathrm{~Hz}), 111.7\left(\mathrm{~d}, J_{\mathrm{C}-\mathrm{F}}=22.5 \mathrm{~Hz}\right), 106.8,55.8,39.4,35.8,35.6,21.0,13.2$.

1-(3'-(2-(6-(2,5-Dimethyl-1H-pyrrol-1-yl)-4-methylpyridin-2-yl)ethyl)-5'-fluoro-[1,1'biphenyl]-4-yl)-N-methylmethanamine (35b): Compound 35b was prepared via Suzuki cross-coupling and reductive amination. 34b was synthesized according to general procedure D using $\mathrm{Pd}\left(\mathrm{PPh}_{3}\right)_{4}(29.2 \mathrm{mg}), \mathrm{K}_{2} \mathrm{CO}_{3}(143 \mathrm{mg})$, boronic acid 31c $(115.3 \mathrm{mg})$, and $\mathbf{3 0}$ (186 $\mathrm{mg}, 0.5 \mathrm{mmol}) .35 \mathrm{~b}$ was synthesized according to general procedure $\mathrm{E}$ using $\mathrm{N}$-methylamine hydrochloride (109 mg), $\mathrm{NaOAc}(135 \mathrm{mg}), \mathbf{3 4 b}$, and $\mathrm{NaBH}_{4}(127 \mathrm{mg})$. 35b was isolated as a light-yellow oil (127.5 mg, 60\%) after flash column chromatography (methanol: DCM 1: 9). ${ }^{1} \mathrm{H}$ NMR (500 MHz, $\mathrm{CDCl}_{3}$ ): $\delta 7.48(\mathrm{~d}, J=8.5 \mathrm{~Hz}, 2 \mathrm{H}), 7.40(\mathrm{~d}, J=8.5 \mathrm{~Hz}, 2 \mathrm{H}), 7.14(\mathrm{~s}$, $1 \mathrm{H}), 7.07$ (d, $J=9.5 \mathrm{~Hz}, 1 \mathrm{H}), 6.91(\mathrm{~s}, 1 \mathrm{H}), 6.86(\mathrm{~s}, 1 \mathrm{H}), 6.85(\mathrm{~d}, J=9.5 \mathrm{~Hz}, 1 \mathrm{H}), 5.88(\mathrm{~s}, 2 \mathrm{H})$, $3.82(\mathrm{~s}, 2 \mathrm{H}), 3.11-3.10(\mathrm{~m}, 4 \mathrm{H}), 2.48(\mathrm{~s}, 3 \mathrm{H}), 2.35(\mathrm{~s}, 3 \mathrm{H}), 2.10(\mathrm{~s}, 6 \mathrm{H}) ;{ }^{13} \mathrm{C} \mathrm{NMR}(125$ $\left.\mathrm{MHz}, \mathrm{CDCl}_{3}\right): \delta 163.2\left(\mathrm{~d}, J_{\mathrm{C}-\mathrm{F}}=242.5 \mathrm{~Hz}\right), 160.4,151.8,149.6,144.3\left(\mathrm{~d}, J_{\mathrm{C}-\mathrm{F}}=7.5 \mathrm{~Hz}\right)$, $142.8\left(\mathrm{~d}, J_{\mathrm{C}-\mathrm{F}}=7.5 \mathrm{~Hz}\right), 139.2\left(\mathrm{~d}, J_{\mathrm{C}-\mathrm{F}}=2.5 \mathrm{~Hz}\right), 138.1,129.1,128.5,127.2,123.0\left(\mathrm{~d}, J_{\mathrm{C}-\mathrm{F}}\right.$ $=1.3 \mathrm{~Hz}), 122.7,120.3,114.1\left(\mathrm{~d}, J_{\mathrm{C}-\mathrm{F}}=21.3 \mathrm{~Hz}\right), 111.5\left(\mathrm{~d}, J_{\mathrm{C}-\mathrm{F}}=21.3 \mathrm{~Hz}\right), 106.8,55.0$, $39.4,35.6,35.3,21.0,13.2$. 


\section{NOS Enzyme Inhibition Assay}

The NOS inhibitory activity of the studied compounds was measured by the hemoglobin $(\mathrm{Hb}) \mathrm{NO}$ capture assay, in which NO production was monitored by a rapid oxidation of oxyHb to metHb by NO. ${ }^{26}$ Purified NOSs, including rat nNOS, human nNOS, murine macrophage iNOS, and human eNOS used in this study are recombinant enzymes. They are expressed in $E$. coli and purified as previously reported. ${ }^{34-37}$ The assay was done in $100 \mathrm{mM}$ HEPES buffer with $10 \%$ glycerol (pH 7.4) at $37{ }^{\circ} \mathrm{C}$ in the presence of $10 \mu \mathrm{M} \mathrm{L-Arg}, 10 \mu \mathrm{M}$ $\mathrm{H}_{4} \mathrm{~B}, 100 \mu \mathrm{M}$ NADPH, $0.83 \mathrm{mM} \mathrm{CaCl}_{2}, 320$ units $/ \mathrm{mL}$ of calmodulin, and $3 \mu \mathrm{M}$ human oxyhemoglobin. The concentration of $\mathrm{L}-\mathrm{Arg}, 10 \mu \mathrm{M}$, was used as it is sufficient not to cause NOS uncoupling and is close to the $K_{\mathrm{m}}$ values of all three NOS isoforms where competitive inhibitors can be detected effectively. In case of iNOS, $\mathrm{CaCl}_{2}$ and calmodulin were omitted and replaced by HEPES buffer since iNOS activation is calcium-independent. The assay was performed in 96-well plates using a Biotek Gen $5^{\mathrm{TM}}$ microplate reader. The NOS enzymes and hemoglobin were dispensed automatically by the plate reader. NO production was kinetically monitored at $410 \mathrm{~nm}$ for $6 \mathrm{~min}$. The inhibition constants $\left(K_{\mathrm{i}}\right)$ for all NOSs were calculated from the $\mathrm{IC}_{50}$ values of the dose-response curves using the Cheng-Prusoff equation: $K_{\mathrm{i}}=\mathrm{IC}_{50} /(1+[\mathrm{S}] / K \mathrm{~m})^{27}$ and $K_{\mathrm{m}}$ (human nNOS: $1.6 \mu \mathrm{M}$; rat nNOS: $1.3 \mu \mathrm{M}$; murine iNOS: $8.2 \mu \mathrm{M}$; bovine eNOS: $1.7 \mu \mathrm{M}$; human eNOS: $3.9 \mu \mathrm{M}) .{ }^{38}$ Dose-response curves were constructed from seven to nine test concentrations $(200 \mu \mathrm{M}-50 \mathrm{nM})$, and $\mathrm{IC}_{50}$ values were calculated by nonlinear regression using GraphPad Prism software. The calculated standard deviations from dose-response curves of the assays were less than $10 \%$ with all NOSs. To confirm that the change in the absorbance of hemoglobin is caused by the released NO without any interference from possible binding between the 2-aminopyridine moiety in 6-19 and the heme in hemoglobin, a control experiment was performed by monitoring the UV-vis absorption of hemoglobin without and in the presence of compound 12. The result (Figure S4) revealed that there is no change in either $\lambda_{\max }$ or the absorbance intensity of the UV-vis spectrum of hemoglobin after the addition of $\mathbf{1 2}$, indicating that there is no interaction between these two species.

\section{PAMPA-BBB Assay}

BBB penetration was evaluated by the PAMPA-BBB assay, in which a porcine brain lipid was used as an artificial membrane. ${ }^{28,39,40}$ The five commercial drugs, phosphate buffer saline (PBS, $10 \mathrm{mM}$ ), DMSO (for biology), and dodecane (analytical standard) were purchased from Sigma Aldrich and Acros Organic. The porcine brain lipid (PBL) was obtained from Avanti Polar Lipids (100 mg, powder, Cat. \# 141101P). The donor plate was a 96-well filter plate with hydrophobic polyvinylidene fluoride (PVDF) membrane (pore size $0.45 \mu \mathrm{m}$, non-sterile, Cat. \# MAIPNTR10), and the acceptor plate was a 96-well transport receiver plate (Cat. \# MATRNPS50), both from EDM Millipore Sigma. The 96-well UV plate with a flat bottom obtained from Greiner Bio-One was used for UV measurements (Cat. \# 655801). Test compounds were first dissolved in DMSO to make a $10 \mathrm{mM}$ stock solution. $20 \mu \mathrm{L}$ of the stock solution was then diluted with $980 \mu \mathrm{L}$ of $10 \mathrm{mM}$ PBS buffer (pH $=7.5)$ to generate a final concentration of $200 \mu \mathrm{M}$ (2\% DMSO). The acceptor plate was filled with $250 \mu \mathrm{L}$ of $10 \mathrm{mM}$ PBS. The donor plate was first coated with $4 \mu \mathrm{L}$ of PBL (20 $\mathrm{mg} / \mathrm{mL}$ in dodecane). $250 \mu \mathrm{L}$ of a test compound $(200 \mu \mathrm{M})$ was subsequently added to the 
donor plate. The donor plate was then carefully placed on top of the acceptor plate to make a "sandwich", which was incubated at $25{ }^{\circ} \mathrm{C}$ for $17 \mathrm{~h}$ in a saturated humidity atmosphere with an orbital agitation at $100 \mathrm{rpm}$. During this time, compounds diffuse from the donor plate to the acceptor plate. After incubation, $150 \mu \mathrm{L}$ of test solution was taken from each well from both sides (donor and acceptor) and transferred to the UV plate for measurement. The concentration of a compound in each donor and acceptor well was determined by using a standard curve, which was built from its UV absorbance at $\lambda_{\max }$ of various concentrations (1 to $200 \mu \mathrm{M})$. Each compound was measured in triplicate. The effective permeability $\left(\mathrm{P}_{\mathrm{e}}\right)$ was calculated using the following equation ${ }^{41}$ :

$P_{e}=\frac{2.303}{A \cdot\left(t-\tau_{s s}\right)} \cdot \frac{V_{A} \cdot V_{D}}{\left(V_{A}+V_{D}\right)} \cdot \lg \left[1-\left(\frac{V_{A}+V_{D}}{(1-R) \cdot V_{D}}\right) \cdot\left(\frac{C_{A}(t)}{C_{D}(0)}\right)\right]$, where $\mathrm{P}_{\mathrm{e}}$ is the effective permeability $(\mathrm{cm} / \mathrm{s}), \mathrm{V}_{\mathrm{A}}$ and $\mathrm{V}_{\mathrm{D}}$ are the volume of the acceptor and donor well $\left(0.25 \mathrm{~cm}^{3}\right)$, respectively, $C_{A}(t)$ is the concentration of the acceptor well at time $t, C_{D}(0), C_{D}(t)$ is the concentration of the donor well at $t_{0}$ and $t$, respectively, $A$ is the filter well area $\left(0.21 \mathrm{~cm}^{2}\right)$. $t$ is the incubation time (s). $\tau_{\mathrm{ss}}$ is the time to reach a steady state (usually very short compared to the incubation time). $\mathrm{R}$ is the retention membrane factor and was calculated using the following equation: $R=\left[1-\frac{C_{D}(t)}{C_{D}(0)}-\frac{V_{A}}{V_{D}} \cdot \frac{C_{A}(t)}{C_{D}(0)}\right] . \mathrm{P}_{\mathrm{e}}$ was reported as an average of triplicate with a standard deviation.

\section{Caco-2 Assay}

The bidirectional Caco-2 assay was performed by Sai Life Sciences, Pune, India. Caco-2 cells were first grown in Dulbecco's Modified Eagles medium until they attained 85-90\% confluence. The cells were then trypsinized and seeded into 24 -well plates at a density of 0.6 $\times 10^{5}$ cells/insert. The plates were kept in a $\mathrm{CO}_{2}$ incubator at $37^{\circ} \mathrm{C}$ for 21 days, and the medium was changed every alternative day. TEER instrument was used to validate the

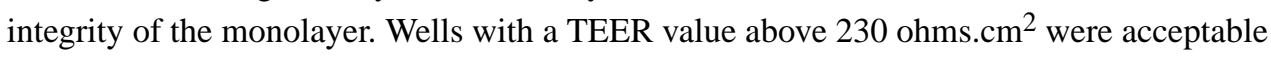
for the assay. Test compounds were dissolved in DMSO to make a $5 \mathrm{mM}$ stock solution, which was further diluted 1000-fold in Hank's Balanced Salt Solution (HBSS) buffer to obtain a final concentration of $5 \mu \mathrm{M}(0.1 \%$ DMSO). Studied compounds were applied to either the apical (A $\rightarrow$ B direction) or the basal side (B $\rightarrow$ A direction). $50 \mu \mathrm{L}$ of test compounds in the receiver compartment was taken at different time points $(0,15,30,60$ and $90 \mathrm{~min}$ ) to measure the permeability of compounds. The concentration of test compounds at each time point was analyzed by LC-MS/MS. The apparent permeability $\left(\mathrm{P}_{\text {app }}\right)$ was calculated using the following equation: $\mathrm{P}_{\text {app }}=(\mathrm{dQ} / \mathrm{dt}) / \mathrm{C}_{0} \cdot \mathrm{A}$, where $\mathrm{dQ} / \mathrm{dt}$ is the linear slope of test compound concentration in the receiver chamber over time, $\mathrm{C}_{0}$ is the initial concentration of the compounds in the donor well, $\mathrm{A}$ is the filter well area $\left(0.7 \mathrm{~cm}^{2}\right)$. The efflux ratio is defined by the ratio of the apparent permeability of $\mathrm{B} \rightarrow \mathrm{A}$ over that of $\mathrm{A} \rightarrow$ B. An ER value above 3 indicates that a compound is possibly a substrate of P-pg or other active efflux transporters.

\section{Inhibitor Complex Crystal Preparation}

The sitting drop vapor diffusion method was used to grow crystals at $4{ }^{\circ} \mathrm{C}$ for the heme domains of rat nNOS ( $8 \mathrm{mg} / \mathrm{mL}$ containing $20 \mathrm{mM}$ histidine), the human nNOS K301R/ R354A/G357D mutant ( $10 \mathrm{mg} / \mathrm{mL})$, and human eNOS $(7 \mathrm{mg} / \mathrm{mL})$. The crystal growth conditions were as described previously. ${ }^{22}$ Fresh crystals were first passed stepwise through 
cryoprotectant solutions and then soaked with $5-10 \mathrm{mM}$ inhibitor for $3-4 \mathrm{~h}$ at $4{ }^{\circ} \mathrm{C}$ before being flash cooled with liquid nitrogen and stored until data collection. The presence of an acetate ion near the heme active site in bovine eNOS caused interference in the binding mode of some inhibitors. ${ }^{42}$ The high concentration of magnesium acetate in the heNOS growth conditions may also introduce an acetate near the active site that may influence the binding mode of inhibitors. To avoid having this acetate in the structure, the magnesium acetate in the cryoprotectant solution was replaced with $\mathrm{MgCl}_{2}$.

\section{X-ray Diffraction Data Collection, Data Processing, and Structural Refinement}

The cryogenic (100 K) X-ray diffraction data were collected remotely at the Stanford Synchrotron Radiation Lightsource (SSRL) or Advanced Light Source (ALS) through the data collection control software Blu-Ice ${ }^{43}$ and a crystal-mounting robot. When a CCD detector was used, $100-125^{\circ}$ of data were typically collected with $0.5^{\circ}$ per frame. If a Pilatus pixel array detector was used, $140-160^{\circ}$ of fine-sliced data were collected with a $0.2^{\circ}$ per frame. Raw CCD data frames were indexed, integrated, and scaled using iMOSFLM, ${ }^{44}$ but the pixel array data were processed with $\mathrm{XDS}^{45}$ and scaled with Aimless. ${ }^{46}$ The binding of inhibitors was detected by initial difference Fourier maps calculated with REFMAC. ${ }^{47}$ The inhibitor molecules were then modeled in $\mathrm{Coot}^{48}$ and refined using REFMAC or PHENIX. ${ }^{49}$ The crystal packing of the $\mathrm{MgCl}_{2}$ soaked heNOS crystals was changed slightly, resulting in a symmetry change from the orthorhombic $\mathrm{P} 22_{1} 2_{1} 2_{1}$ reported previously 36 to monoclinic $\mathrm{P} 2{ }_{1}$, with a $\beta$ angle only $0.6-0.7^{\circ}$ off compared to the original $90^{\circ}$. Therefore, a molecular replacement calculation with PHASER-MR ${ }^{50}$ was needed to solve the structure. In the P2 1 space group, there are two heNOS dimers in the asymmetric unit. Disordering in portions of inhibitors bound in the NOS active sites was often observed, sometimes resulting in poor density quality. However, partial structural features were usually still visible if the contour level of the sigmaA weighted $2 \mathrm{~m}|\mathrm{Fo}|-\mathrm{D}|\mathrm{Fc}|$ map was dropped to $0.5 \sigma$, which afforded the building of reasonable models into the disordered regions. Water molecules were added in PHENIX and checked by Coot. The TLS ${ }^{51}$ protocol was implemented in the final stage of refinements with each subunit as one TLS group. The omit Fo - Fc density maps were calculated by removing inhibitor coordinates from the input PDB file before running one more round of TLS refinement in PHENIX (simulated annealing protocol with a $2000 \mathrm{~K}$ initial temperature). The resulting map coefficients DELFWT and PHDELWT were used to generate maps. For some recent structures, the Polder map facility in PHENIX was used to calculate the omit density map for the bound inhibitors. ${ }^{52}$ The refined structures were validated in Coot before deposition in the Protein Data Bank.

\section{Supplementary Material}

Refer to Web version on PubMed Central for supplementary material.

\section{Acknowledgments}

We are grateful for the generous support from the National Institutes of Health (R01 GM049725, to R.B.S., GM057353 to T.L.P.). H. L. wishes to thank Carla Plaza for her assistance in NOS protein expression and purification; the purified samples were used in both crystallography and enzyme assays. We also wish to thank the SSRL and ALS beamline staff for their support during remote X-ray diffraction data collection. This work made use of the IMSERC at Northwestern University, which has received support from the Soft and Hybrid Nanotechnology 
Experimental (SHyNE) Resource (NSF NNCI-1542205); the State of Illinois and International Institute for Nanotechnology (IIN).

\section{ABBREVIATIONS USED}

\begin{tabular}{|c|c|}
\hline NO & nitric oxide \\
\hline nNOS & neuronal nitric oxide synthase \\
\hline iNOS & inducible nitric oxide synthase \\
\hline eNOS & endothelial nitric oxide synthase \\
\hline hnNOS & human neuronal nitric oxide synthase \\
\hline heNOS & human endothelial nitric oxide synthase \\
\hline L-Arg & L-Arginine \\
\hline FAD & flavin adenine dinucleotide \\
\hline FMN & flavin mononucleotide \\
\hline NADPH & reduced nicotinamide adenine dinucleotide phosphate \\
\hline $\mathbf{H}_{4} \mathbf{B}$ & $(6 R)-5,6,7,8$-tetrahydrobiopterin \\
\hline HEPES & 4-(2-hydroxyethyl)-1-piperazine-ethanesulfonic acid \\
\hline DNA & deoxyribonucleic acid \\
\hline WT & wild type \\
\hline PAMPA & parallel artificial membrane permeability assay \\
\hline BBB & blood-brain barrier \\
\hline CNS & central nervous system \\
\hline P-gp & P-glycoprotein \\
\hline ATP & adenosine triphosphate \\
\hline $\mathbf{E R}$ & efflux ratio \\
\hline $\mathbf{P}_{\mathbf{e}}$ & effective permeability \\
\hline $\mathbf{P}_{\text {app }}$ & apparent permeability \\
\hline
\end{tabular}

\section{References}

1. Garthwaite J, Boulton CL. Nitric oxide signaling in the central nervous system. Annu Rev Physiol. 1995; 57:683-706. [PubMed: 7539993]

2. Bogdan C. Nitric oxide and the immune response. Nat Immunol. 2001; 2:907-916. [PubMed: 11577346] 
3. Marin J, Rodriguezmartinez MA. Nitric oxide, oxygen-derived free-radicals and vascular endothelium. J Auton Pharmacol. 1995; 15:279-307. [PubMed: 8576275]

4. Alderton WK, Cooper CE, Knowles RG. Nitric oxide synthases: structure, function and inhibition. Biochem J. 2001; 357:593-615. [PubMed: 11463332]

5. Knowles RG, Moncada S. Nitric oxide synthases in mammals. Biochem J. 1994; 298:249-258. [PubMed: 7510950]

6. Maccallini C, Amoroso R. Targeting neuronal nitric oxide synthase as a valuable strategy for the therapy of neurological disorders. Neural Regener Res. 2016; 11:1731-1734.

7. Heinrich UR, Helling K. Nitric oxide - a versatile key player in cochlear function and hearing disorders. Nitric Oxide-Biology and Chemistry. 2012; 27:106-116. [PubMed: 22659013]

8. Dusting GJ. Nitric oxide in cardiovascular disorders. J Vasc Res. 1995; 32:143-161. [PubMed: 7772676]

9. Mollace V, Nisticò G. Release of nitric oxide from astroglial cells: a key mechanism in neuroimmune disorders. Adv Neuroimmunol. 1995; 5:421-430. [PubMed: 8746514]

10. De La Torre JC, Stefano GB. Evidence that Alzheimer's disease is a microvascular disorder: the role of constitutive nitric oxide. Brain Res Rev. 2000; 34:119-136. [PubMed: 11113503]

11. Drechsel DA, Estévez AG, Barbeito L, Beckman JS. Nitric oxide-mediated oxidative damage and the progressive demise of motor neurons in ALS. Neurotoxic Res. 2012; 22:251-264.

12. Uehara T, Nakamura T, Yao D, Shi ZQ, Gu Z, Ma Y, Masliah E, Nomura Y, Lipton SA. SNitrosylated protein-disulphide isomerase links protein misfolding to neurodegeneration. Nature. 2006; 441:513-517. [PubMed: 16724068]

13. Torreilles F, Salman-Tabcheh SD, Guérin MC, Torreilles J. Neurodegenerative disorders: the role of peroxynitrite. Brain Res Rev. 1999; 30:153-163. [PubMed: 10525172]

14. Bolanos JP, Almeida A, Stewart V, Peuchen S, Land JM, Clark JB, Heales SJR. Nitric oxidemediated mitochondrial damage in the brain: mechanisms and implications for neurodegenerative diseases. J Neurochem. 1997; 68:2227-2240. [PubMed: 9166714]

15. Silverman RB. Design of selective neuronal nitric oxide synthase inhibitors for the prevention and treatment of neurodegenerative diseases. Acc Chem Res. 2009; 42:439-451. [PubMed: 19154146]

16. Di L, Rong H, Feng B. Demystifying brain penetration in central nervous system drug discovery. J Med Chem. 2013; 56:2-12. [PubMed: 23075026]

17. Mukherjee P, Cinelli MA, Kang S, Silverman RB. Development of nitric oxide synthase inhibitors for neurodegeneration and neuropathic pain. Chem Soc Rev. 2014; 43:6814-6838. [PubMed: 24549364]

18. Labby KJ, Xue F, Kraus JM, Ji H, Mataka J, Li H, Martásek P, Roman LJ, Poulos TL, Silverman RB. Intramolecular hydrogen bonding: a potential strategy for more bioavailable inhibitors of neuronal nitric oxide synthase. Bioorg Med Chem. 2012; 20:2435-2443. [PubMed: 22370337]

19. Silverman RB, Lawton GR, Ranaivo HR, Chico LK, Seo J, Watterson DM. Effect of potential amine prodrugs of selective neuronal nitric oxide synthase inhibitors on blood-brain barrier penetration. Bioorg Med Chem. 2009; 17:7593-7605. [PubMed: 19796958]

20. Xue F, Li H, Delker SL, Fang J, Martásek P, Roman LJ, Poulos TL, Silverman RB. Potent, highly selective, and orally bioavailable gem-difluorinated monocationic inhibitors of neuronal nitric oxide synthase. J Am Chem Soc. 2010; 132:14229-14238. [PubMed: 20843082]

21. Mukherjee P, Li H, Sevrioukova I, Chreifi G, Martásek P, Roman LJ, Poulos TL, Silverman RB. Novel 2,4-disubstituted pyrimidines as potent, selective, and cell-permeable inhibitors of neuronal nitric oxide synthase. J Med Chem. 2015; 58:1067-1088. [PubMed: 25489882]

22. Cinelli MA, Li H, Chreifi G, Poulos TL, Silverman RB. Nitrile in the hole: discovery of a small auxiliary pocket in neuronal nitric oxide synthase leading to the development of potent and selective 2-aminoquinoline inhibitors. J Med Chem. 2017; 60:3958-3978. [PubMed: 28422508]

23. Wang HY, Qin Y, Li H, Roman LJ, Martásek P, Poulos TL, Silverman RB. Potent and selective human neuronal nitric oxide synthase inhibition by optimization of the 2-aminopyridine-based scaffold with a pyridine linker. J Med Chem. 2016; 59:4913-4925. [PubMed: 27050842]

24. Kang S, Li H, Tang W, Martásek P, Roman LJ, Poulos TL, Silverman RB. 2-aminopyridines with a truncated side chain to improve human neuronal nitric oxide synthase inhibitory potency and selectivity. J Med Chem. 2015; 58:5548-5560. [PubMed: 26120733] 
25. Rankovic Z. CNS drug design: balancing physicochemical properties for optimal brain exposure. J Med Chem. 2015; 58:2584-2608. [PubMed: 25494650]

26. Hevel JM, Marletta MA. [25] Nitric-oxide synthase assays. Methods Enzymol. 1994; 233:250258. [PubMed: 7516999]

27. Yung-Chi C, Prusoff WH. Relationship between the inhibition constant (Ki) and the concentration of inhibitor which causes 50 percent inhibition (I50) of an enzymatic reaction. Biochem Pharmacol. 1973; 22:3099-3108. [PubMed: 4202581]

28. Di L, Kerns EH, Fan K, McConnell OJ, Carter GT. High throughput artificial membrane permeability assay for blood-brain barrier. Eur J Med Chem. 2003; 38:223-232. [PubMed: 12667689]

29. Di L, Kerns EH, Bezar IF, Petusky SL, Huang Y. Comparison of blood-brain barrier permeability assays: in situ brain perfusion, MDR1-MDCKII and PAMPA-BBB. J Pharm Sci. 2009; 98:19801991. [PubMed: 18837012]

30. Könczöl Á, Müller J, Földes E, Béni Z, Végh K, Kéry Á, Balogh GT. Applicability of a bloodbrain barrier specific artificial membrane permeability assay at the early stage of natural productbased CNS drug discovery. J Nat Prod. 2013; 76:655-663. [PubMed: 23565574]

31. Patil AG, D’Souza R, Dixit N, Damre A. Validation of quinidine as a probe substrate for the in vitro P-gp inhibition assay in Caco-2 cell monolayer. Eur J Drug Metab Pharmacokinet. 2011; 36:115. [PubMed: 21725799]

32. Wager TT, Hou X, Verhoest PR, Villalobos A. Moving beyond rules: the development of a central nervous system multiparameter optimization (CNS MPO) approach to enable alignment of druglike properties. ACS Chem Neurosci. 2010; 1:435-449. [PubMed: 22778837]

33. Di, L., Kerns, EH. Drug-like Properties: Concepts, Structure Design, and Methods from ADME to Toxiciy Optimization. 2. Elsevier; Amsterdam: 2016. p. 329

34. Gerber NC, De Montellano PRO. Neuronal nitric oxide synthase: expression in Escherichia coli, irreversible inhibition by phenyldiazene, and active site topology. J Biol Chem. 1995; 270:1779117796. [PubMed: 7543092]

35. Hevel JM, White KA, Marletta MA. Purification of the inducible murine macrophage nitric oxide synthase. Identification as a flavoprotein. J Biol Chem. 1991; 266:22789-91. [PubMed: 1720773]

36. Li H, Jamal J, Plaza C, Pineda SH, Chreifi G, Jing Q, Cinelli MA, Silverman RB, Poulos TL. Structures of human constitutive nitric oxide synthases. Acta Crystallogr, Sect D: Struct Biol. 2014; 70:2667-2674.

37. Roman LJ, Sheta EA, Martasek P, Gross SS, Liu Q, Masters BS. High-level expression of functional rat neuronal nitric oxide synthase in Escherichia coli. Proc Natl Acad of Sci U S A. 1995; 92:8428-8432. [PubMed: 7545302]

38. Leber A, Hemmens B, Klösch B, Goessler W, Raber G, Mayer B, Schmidt K. Characterization of recombinant human endothelial nitric-oxide synthase purified from the yeast Pichia pastoris. J Biol Chem. 1999; 274:37658-37664. [PubMed: 10608822]

39. Cahlíková L, Pérez DI, Štěpánková Š, Chlebek J, Šafratová M, Hošt’álková A, Opletal L. In vitro inhibitory effects of 8-O-demethylmaritidine and undulatine on acetylcholinesterase and their predicted penetration across the blood-brain barrier. J Nat Prod. 2015; 78:1189-1192. [PubMed: 26030662]

40. Teixidó M, Zurita E, Malakoutikhah M, Tarragó T, Giralt E. Diketopiperazines as a tool for the study of transport across the blood-brain barrier (BBB) and their potential use as BBB-shuttles. J Am Chem Soc. 2007; 129:11802-11813. [PubMed: 17764181]

41. Müller J, Essô K, Dargó G, Könczöl Á, Balogh GT. Tuning the predictive capacity of the PAMPABBB model. Eur J Pharm Sci. 2015; 79:53-60. [PubMed: 26344358]

42. Cinelli MA, Li H, Pensa AV, Kang S, Roman LJ, Martásek P, Poulos TL, Silverman RB. Phenyl ether- and aniline-containing 2-aminoquinolines as potent and selective inhibitors of neuronal nitric oxide synthase. J Med Chem. 2015; 58:8694-8712. [PubMed: 26469213]

43. McPhillips TM, McPhillips SE, Chiu HJ, Cohen AE, Deacon AM, Ellis PJ, Garman E, Gonzalez A, Sauter NK, Phizackerley RP, Soltis SM, Kuhn P. Blu-ice and the distributed control system: software for data acquisition and instrument control at macromolecular crystallography beamlines. J Synchrotron Radiat. 2002; 9:401-406. [PubMed: 12409628] 
44. Battye TGG, Kontogiannis L, Johnson O, Powell HR, Leslie AGW. iMOSFLM: a new graphical interface for diffraction-image processing with MOSFLM. Acta Crystallogr, Sect D: Biol Crystallogr. 2011; 67:271-281. [PubMed: 21460445]

45. Kabsch W. XDS. Acta Crystallogr, Sect D: Biol Crystallogr. 2010; 66:125-132. [PubMed: 20124692]

46. Evans P. Scaling and assessment of data quality. Acta Crystallogr, Sect D: Biol Crystallogr. 2006; 62:72-82. [PubMed: 16369096]

47. Murshudov GN, Vagin AA, Dodson EJ. Refinement of macromolecular structures by the maximum-likelihood method. Acta Crystallogr, Sect D: Struct Biol. 1997; 53:240-255.

48. Emsley P, Cowtan K. Coot: model-building tools for molecular graphics. Acta Crystallogr, Sect D: Struct Biol. 2004; 60:2126-2132.

49. Adams PD, Afonine PV, Bunkoczi G, Chen VB, Davis IW, Echols N, Headd JJ, Hung LW, Kapral GJ, Grosse-Kunstleve RW, McCoy AJ, Moriarty NW, Oeffner R, Read RJ, Richardson DC, Richardson JS, Terwilliger TC, Zwart PH. PHENIX: a comprehensive Python-based system for macromolecular structure solution. Acta Crystallogr, Sect D: Struct Biol. 2010; 66:213-221.

50. McCoy AJ, Grosse-Kunstleve RW, Adams PD, Winn MD, Storoni LC, Read RJ. Phaser crystallographic software. J Appl Crystallogr. 2007; 40:658-674. [PubMed: 19461840]

51. Winn MD, Isupov MN, Murshudov GN. Use of TLS parameters to model anisotropic displacements in macromolecular refinement. Acta Crystallogr, Sect D: Struct Biol. 2001; 57:122133.

52. Liebschner D, Afonine PV, Moriarty NW, Poon BK, Sobolev OV, Terwilliger TC, Adams PD. Polder maps: improving OMIT maps by excluding bulk solvent. Acta Crystallogr, Sect D: Struct Biol. 2017; 73:148-157. [PubMed: 28177311] 

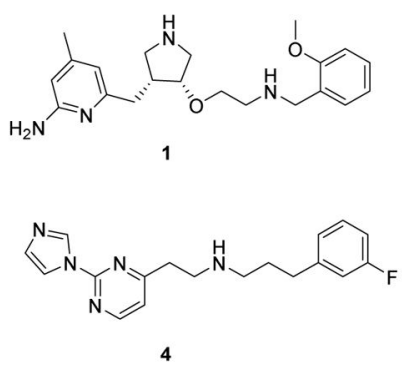

4
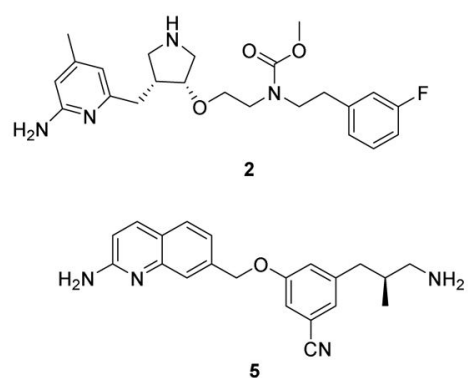
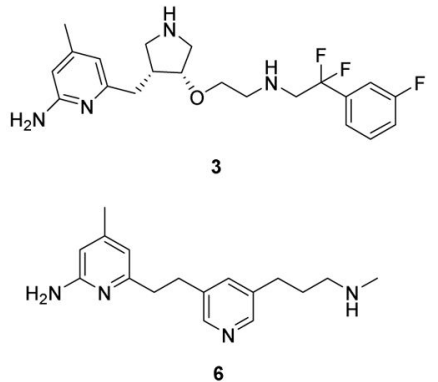

Figure 1.

Reported nNOS inhibitors with some improved pharmacokinetic properties 


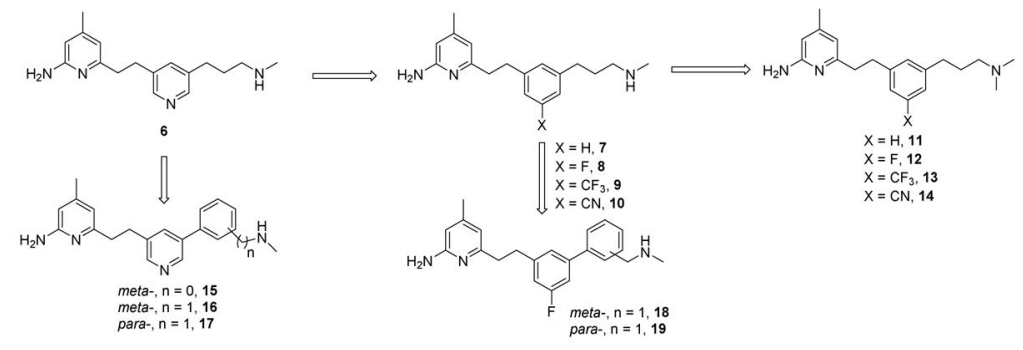

Figure 2.

Structural modification of lead compound $\mathbf{6}$ to improve its permeability 

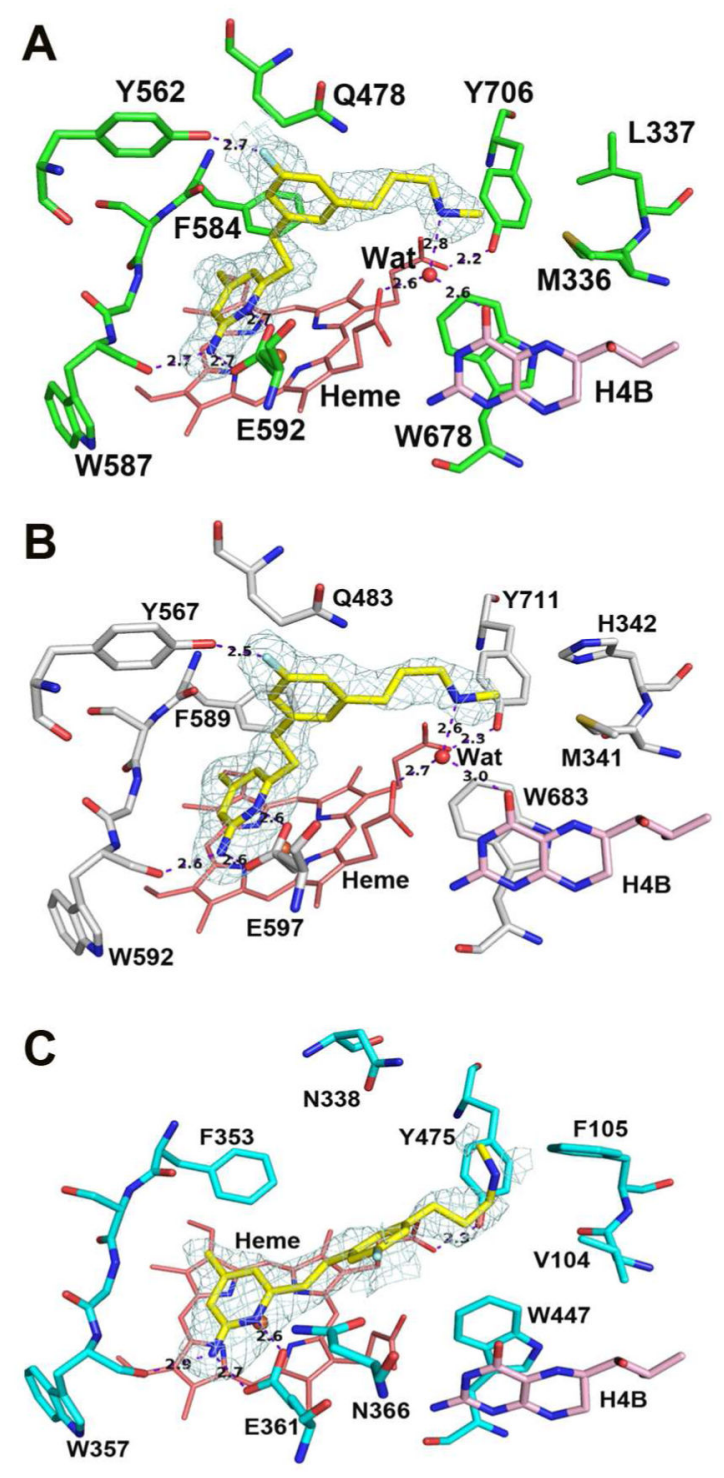

Figure 3.

Active site structure of 8 bound to $\operatorname{rnNOS}(\mathrm{A}), \operatorname{hnNOS}(\mathrm{B})$, and heNOS (C). For this and all following structural figures major $\mathrm{H}$-bonds are depicted with dashed lines and distances are labeled in $\AA$. The Fo - Fc omit electron density for the bound inhibitor is contoured at $2.5 \sigma$. All of the structural figures were prepared with PyMol (www.pymol.org). 

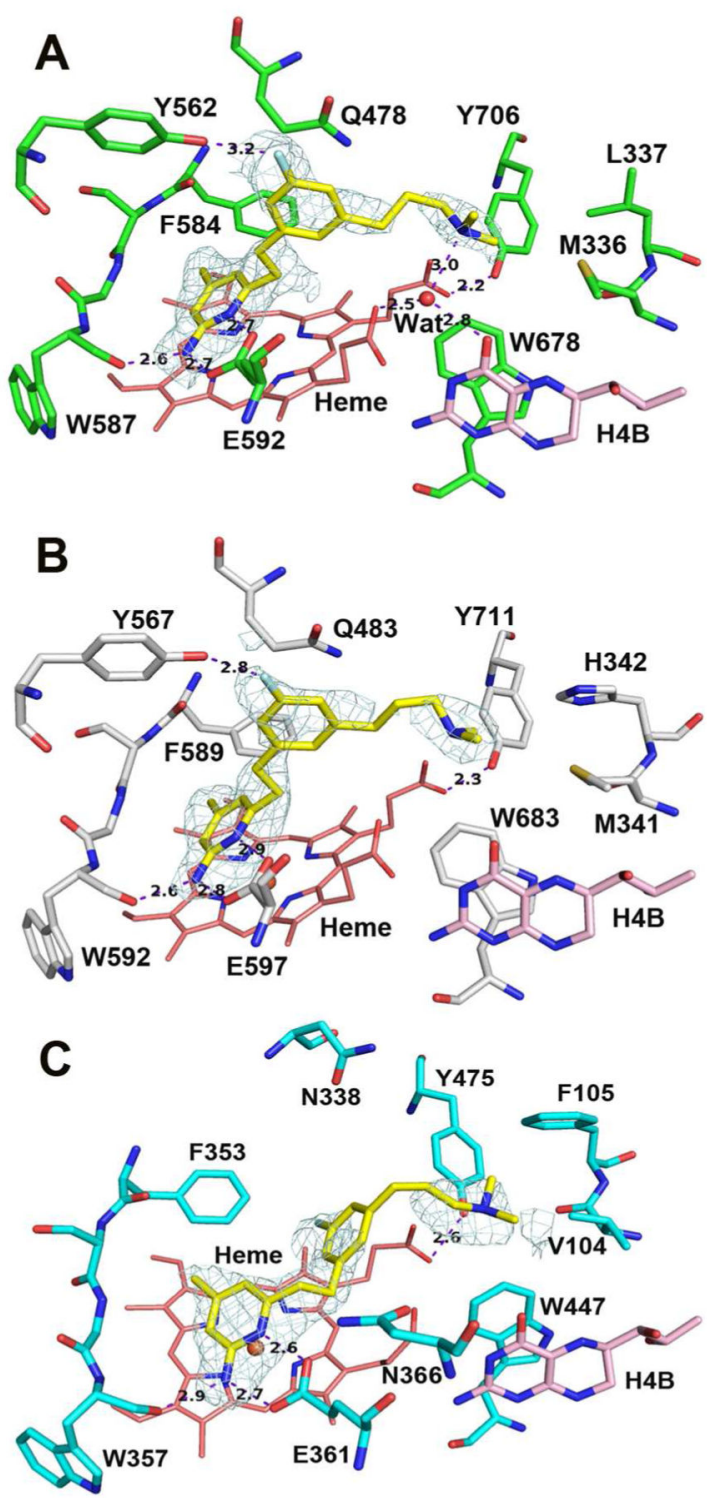

Figure 4.

Active site structures of $\mathbf{1 2}$ bound to $\operatorname{rnNOS}(\mathrm{A}), \operatorname{hnNOS}(\mathrm{B})$, and heNOS (C). The absence of the $\mathrm{H}_{4} \mathrm{~B}$ site water in the hnNOS structure is likely the result of the moderate data resolution. 
A
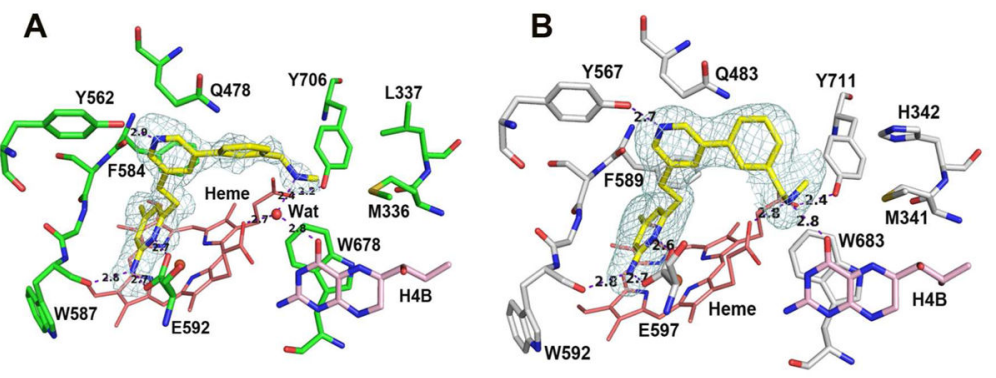

Figure 5.

Active site structures of $\mathbf{1 6}$ bound to rnNOS (A) and hnNOS (B). 

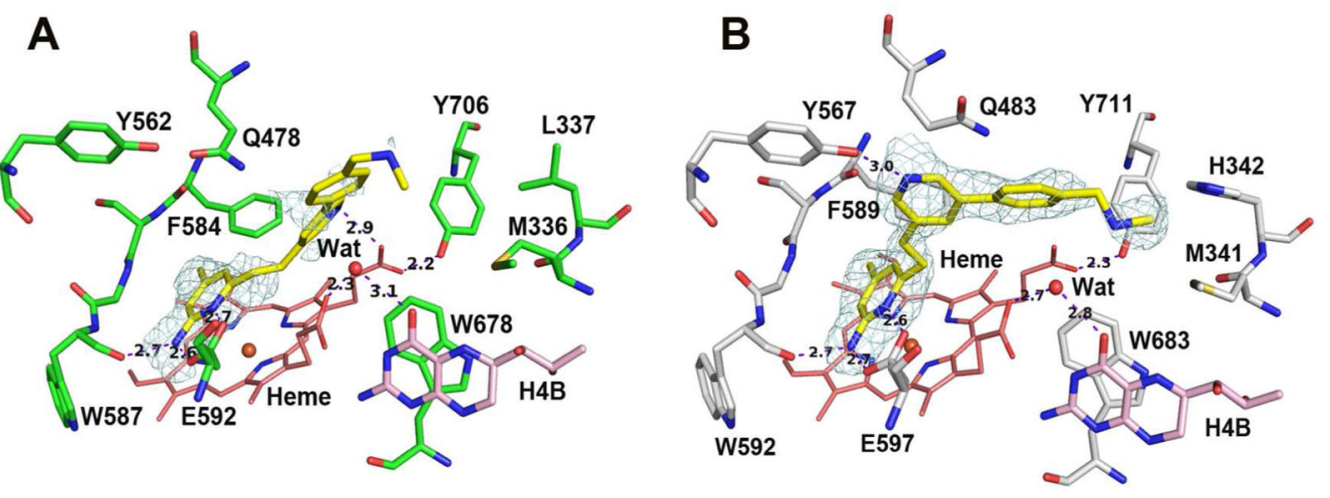

Figure 6.

Active site structures of $\mathbf{1 7}$ bound to rnNOS (A) and hnNOS (B). 

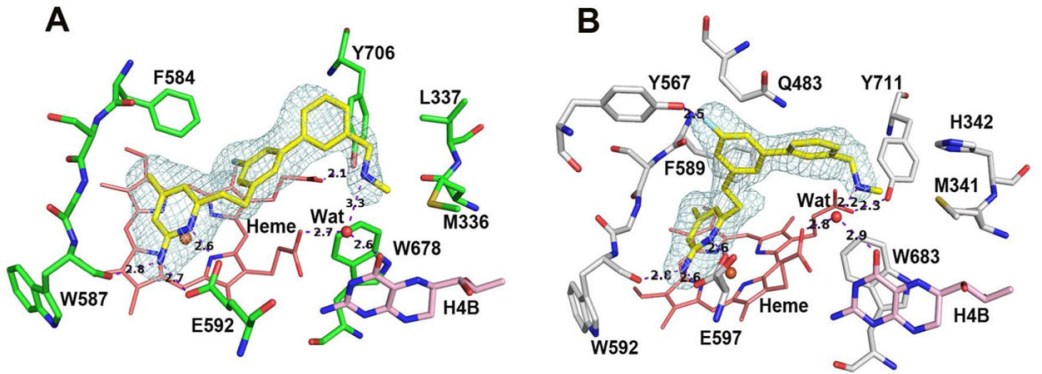

Figure 7.

Active site structures of $\mathbf{1 8}$ bound to $\operatorname{rnNOS}(\mathrm{A})$ and hnNOS (B). The electron density displayed here was calculated by the Polder map function in PHENIX and contoured at 3.5 $\sigma$. 

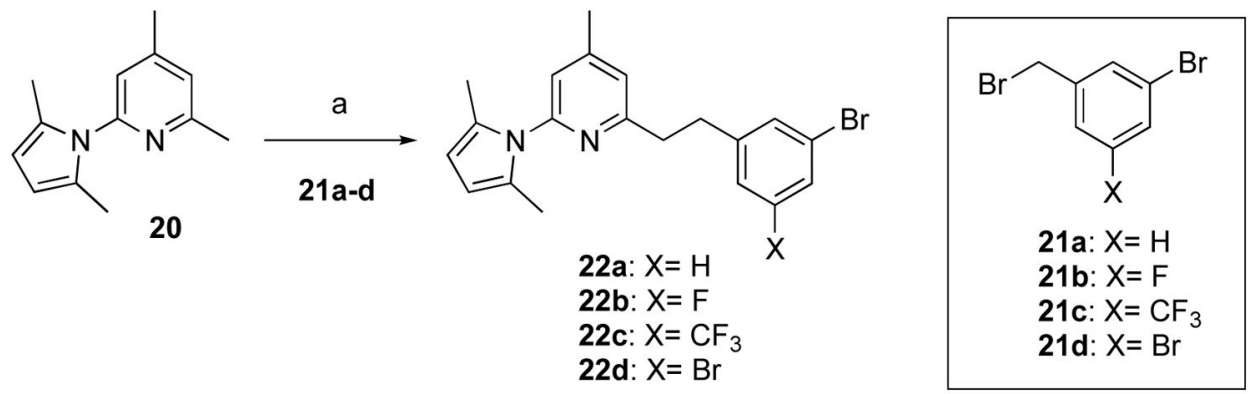

Scheme 1.

Reagents and conditions: Benzylic bromide 21a, 21b, 21c, or 21d, $n$-BuLi, THF, $-78^{\circ} \mathrm{C}$ to $0{ }^{\circ} \mathrm{C}$ then $-78^{\circ} \mathrm{C}$. 


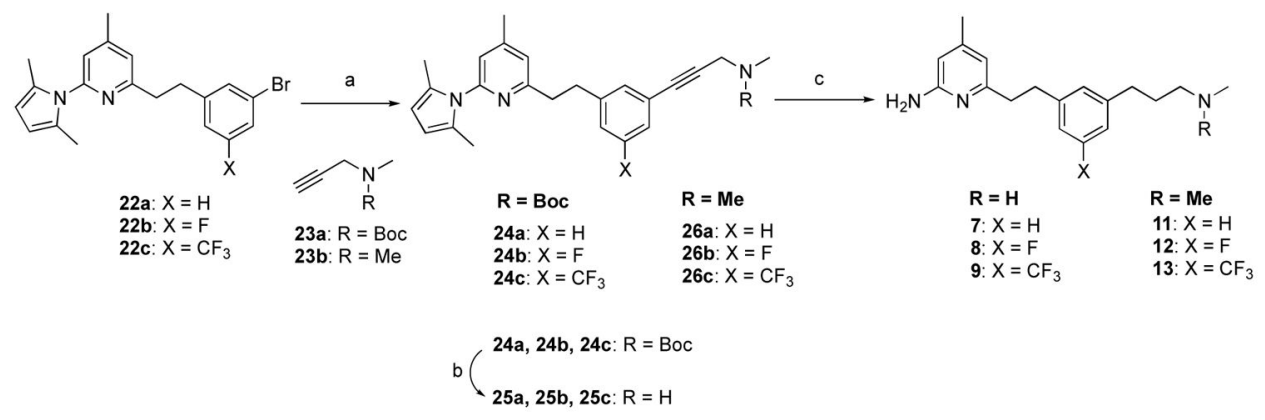

Scheme 2.

Reagents and conditions: (a) 23a or 23b, $\mathrm{Pd}\left(\mathrm{PPh}_{3}\right)_{4}$, CuI, TEA, $90{ }^{\circ} \mathrm{C}, 20 \mathrm{~h}$; (b) $20 \%$ TFA in $\mathrm{CH}_{2} \mathrm{Cl}_{2}$, r.t., 1 h; (c) (i) $\mathrm{Pd} / \mathrm{C}, \mathrm{H}_{2}, \mathrm{MeOH}$, r.t., 20 h, (ii) $\mathrm{NH}_{2} \mathrm{OH} \cdot \mathrm{HCl}$, EtOH/ $\mathrm{H}_{2} \mathrm{O}$ (2:1), $100{ }^{\circ} \mathrm{C}, 20 \mathrm{~h}$. 

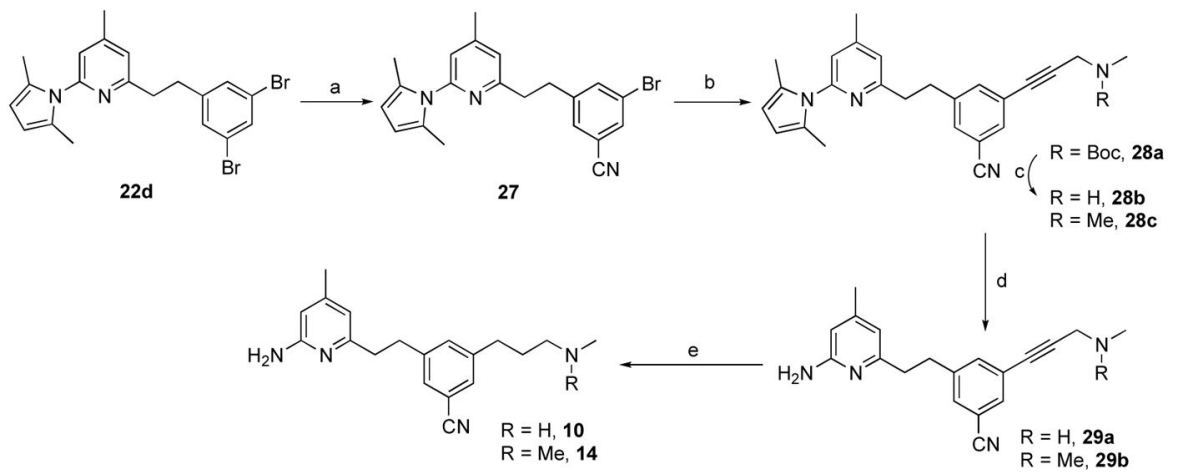

Scheme 3.

Reagents and conditions: (a) $\mathrm{CuCN}$ (1 equiv.), pyridine (1 equiv.), DMF, $150{ }^{\circ} \mathrm{C}$; (b) $23 \mathrm{a}$ or 23b, $\mathrm{Pd}\left(\mathrm{PPh}_{3}\right)_{4}$, CuI, TEA, $90{ }^{\circ} \mathrm{C}, 20$ h; (c) $20 \%$ TFA in $\mathrm{CH}_{2} \mathrm{Cl}_{2}$, r.t., 1 h; (d) $\mathrm{NH}_{2} \mathrm{OH} . \mathrm{HCl}$, $\mathrm{EtOH} / \mathrm{H}_{2} \mathrm{O}(2: 1), 100{ }^{\circ} \mathrm{C}, 20$ h; (e) $\mathrm{Pd} / \mathrm{C}, \mathrm{H}_{2}, \mathrm{MeOH}$, r.t., 20 h. 

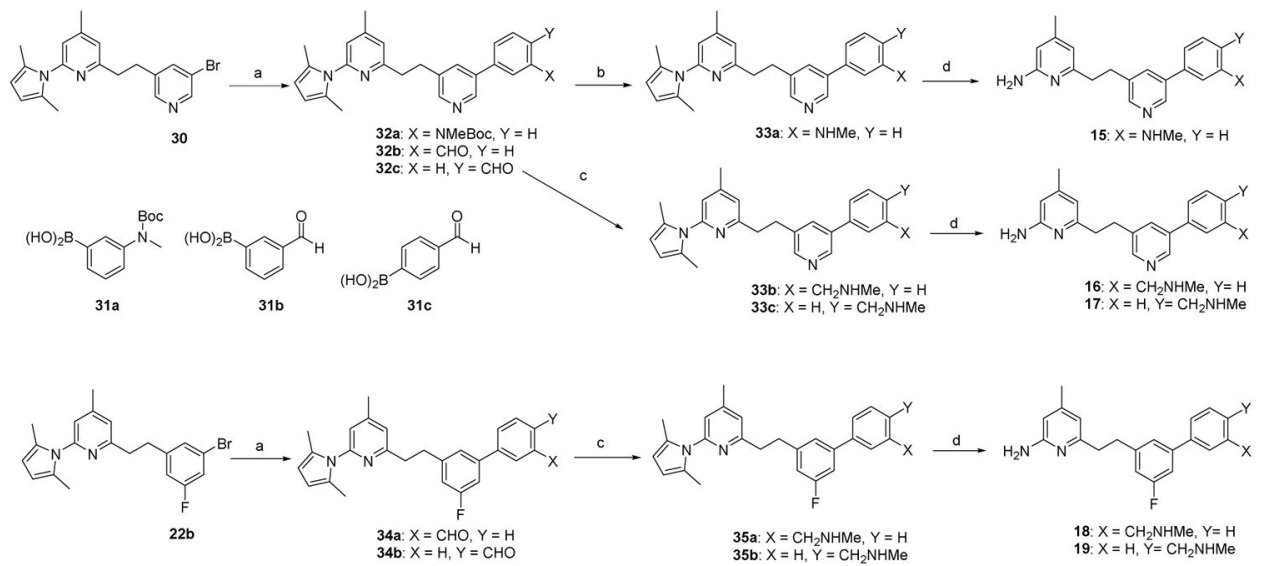

Scheme 4.

Reagents and conditions: (a) boronic acid (31a, 31b or 31c), $\mathrm{K}_{2} \mathrm{CO}_{3}, \mathrm{Pd}\left(\mathrm{PPh}_{3}\right)_{4}, \mathrm{THF} /$ water (4/1), $80{ }^{\circ} \mathrm{C}, 20 \mathrm{~h}$; (b) $20 \%$ TFA in $\mathrm{CH}_{2} \mathrm{Cl}_{2}$, r.t., $1 \mathrm{~h}$; (c) (i) $\mathrm{N}$-methylamine hydrochloride salt, $\mathrm{NaOAc}, \mathrm{MeOH}$, r.t, $15 \mathrm{~min}$ (ii) $\mathrm{NaBH}_{4}, \mathrm{MeOH}, 0^{\circ} \mathrm{C}$ to r.t., 1 h; (d) $\mathrm{NH}_{2} \mathrm{OH} . \mathrm{HCl}$, $\mathrm{EtOH} / \mathrm{H}_{2} \mathrm{O}(2: 1), 100{ }^{\circ} \mathrm{C}, 20 \mathrm{~h}$. 


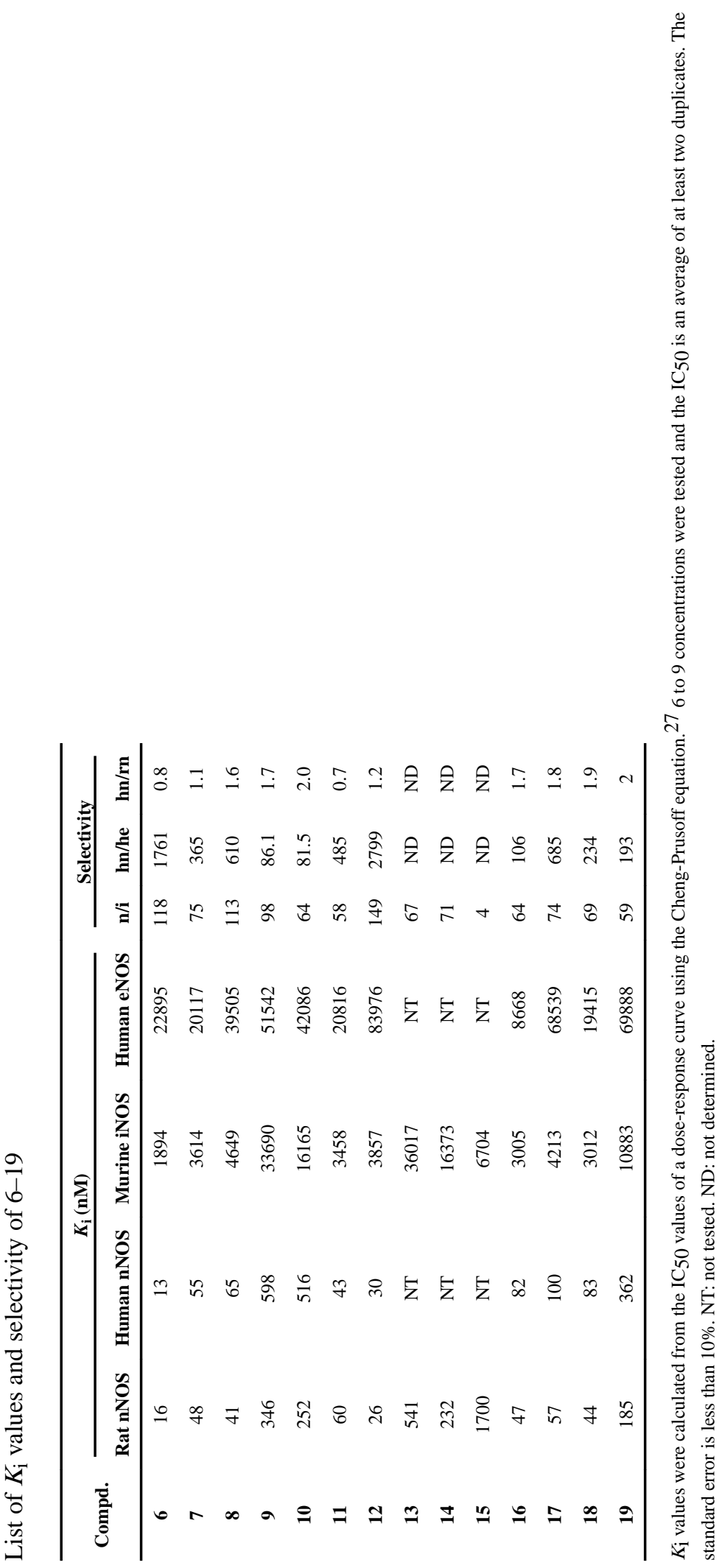


Table 2

Effective permeability $\left(\mathrm{P}_{\mathrm{e}}\right)$ of 5 commercial drugs and nNOS inhibitors in the PAMPA-BBB assay ${ }^{a}$

\begin{tabular}{|c|c|c|c|c|}
\hline Compound & $\log \mathrm{D}^{b}$ & Reported $P_{e}\left(10^{-6} \mathrm{~cm} \mathrm{~s}^{-1}\right)^{c}$ & Determined $P_{\mathrm{e}}\left(10^{-6} \mathrm{~cm} \mathrm{~s}^{-1}\right)^{d}$ & Prediction \\
\hline Verapamil & & 16 & $21.30 \pm 1.50$ & \\
\hline Desipramine & & 12 & $20.52 \pm 0.64$ & \\
\hline Chlorpromazine & & 6.5 & $8.04 \pm 0.41$ & \\
\hline Dopamine & & 0.2 & $0.12 \pm 0.011$ & \\
\hline Theophylline & & 0.12 & $0.15 \pm 0.04$ & \\
\hline 7 & 0.21 & & $10.4 \pm 0.75$ & CNS (+) \\
\hline 12 & 1.28 & & $14.8 \pm 0.69$ & CNS (+) \\
\hline 16 & 0.59 & & $5.56 \pm 0.18$ & CNS (+) \\
\hline 18 & 1.93 & & $17.41 \pm 0.50$ & CNS (+) \\
\hline
\end{tabular}

${ }^{a}$ All assays were performed over $17 \mathrm{~h}$ at a concentration of $200 \mu \mathrm{M}$.

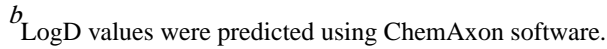

${ }^{c}$ Effective permeability values from literature. ${ }^{28}$

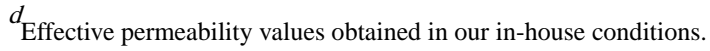




\section{롤 \\ 亩}
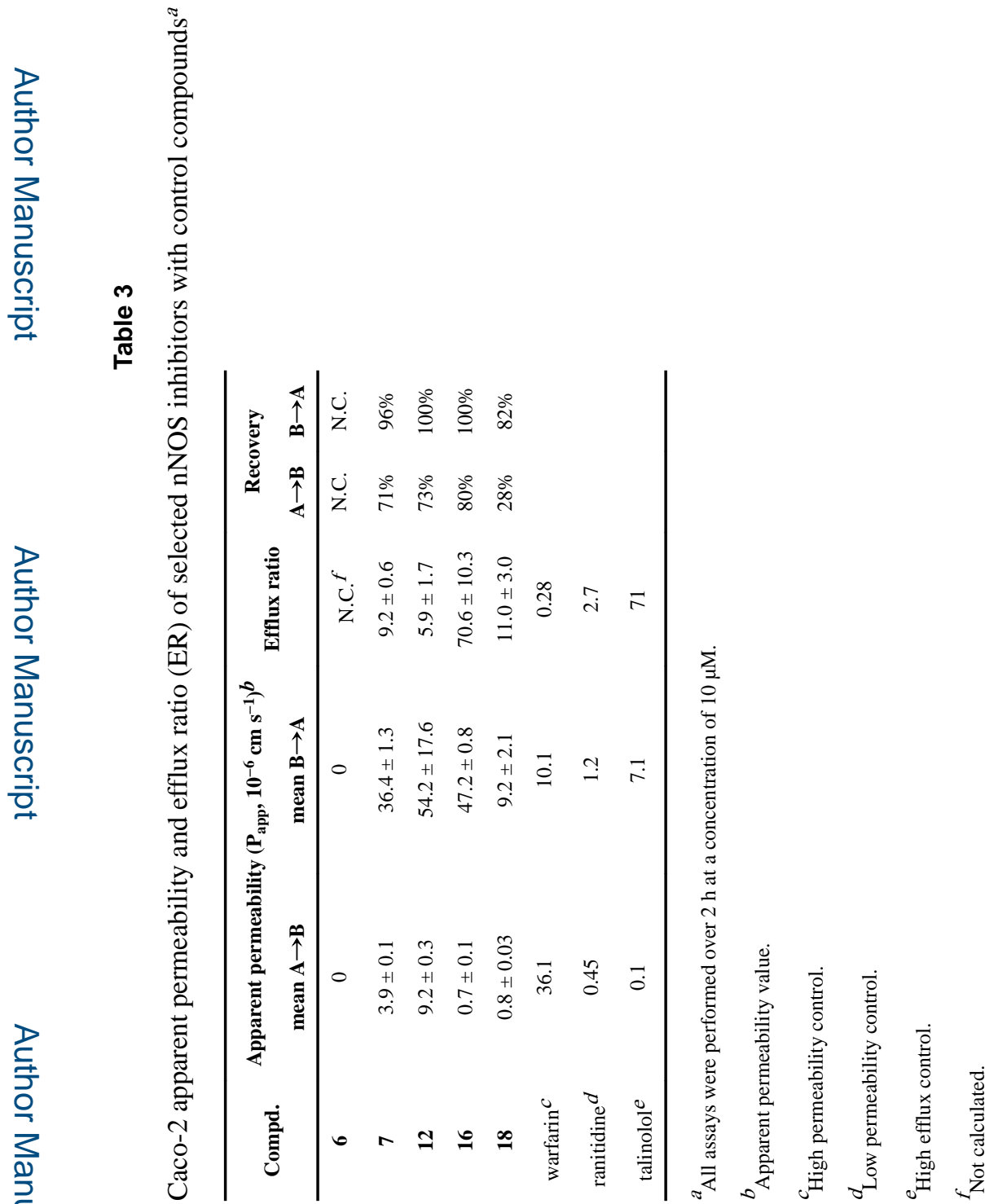

J Med Chem. Author manuscript; available in PMC 2018 November 22. 